\title{
The Economics of Long-Term Global Climate Change
}

\author{
A Preliminary Assessment
}

Report of an Interagency Task Force

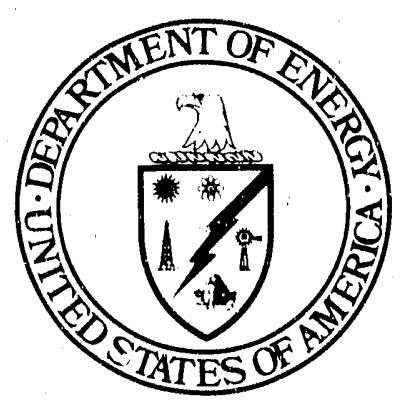

September 1990

United States Department of Energy Office of Policy, Planning and Analysis

Washington, DC 20585 


\section{CONTENTS}

List of Tables $\ldots \ldots \ldots \ldots \ldots \ldots \ldots \ldots \ldots \ldots \ldots \ldots \ldots \ldots \ldots \ldots \ldots \ldots \ldots \ldots \ldots$ iii

Executive Summary $\ldots \ldots \ldots \ldots \ldots \ldots \ldots \ldots \ldots \ldots \ldots \ldots \ldots \ldots \ldots \ldots$ iv

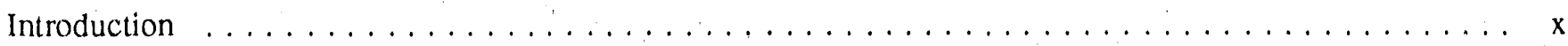

I. Background $\ldots \ldots \ldots \ldots \ldots \ldots \ldots \ldots \ldots \ldots \ldots \ldots \ldots \ldots \ldots \ldots \ldots \ldots \ldots \ldots \ldots$

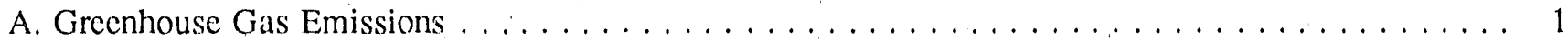

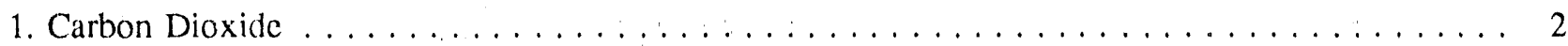

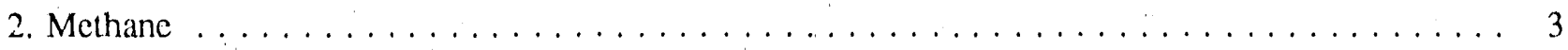

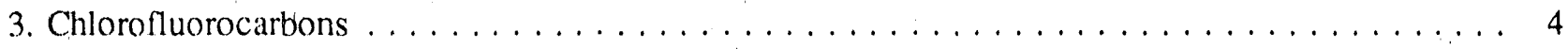

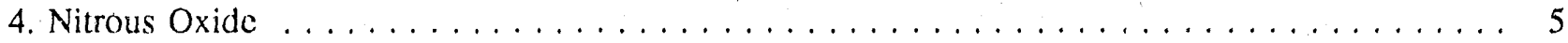

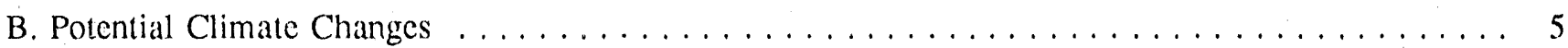

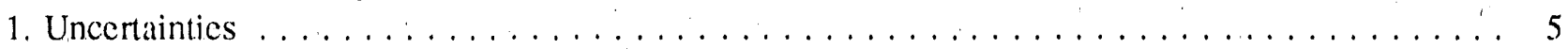

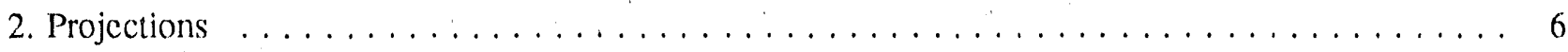

C. Policy Alternatives $\ldots \ldots \ldots \ldots \ldots \ldots \ldots \ldots \ldots \ldots \ldots \ldots \ldots \ldots \ldots \ldots \ldots \ldots$

II. Adaptation: Living with Global Warming $\ldots \ldots \ldots \ldots \ldots \ldots \ldots \ldots \ldots \ldots$

A. Climate and the Economy $\ldots \ldots \ldots \ldots \ldots \ldots \ldots \ldots \ldots \ldots \ldots \ldots \ldots \ldots$

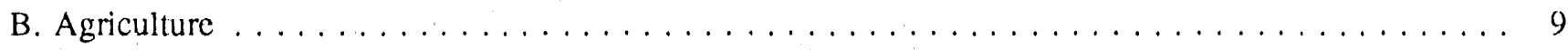

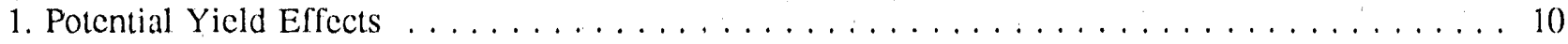

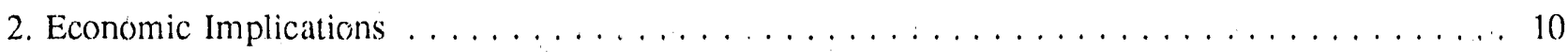

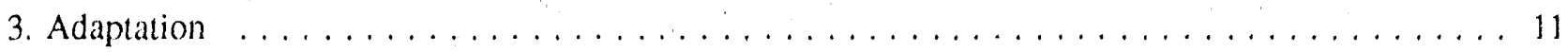

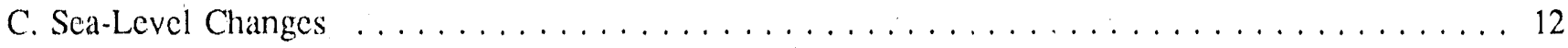

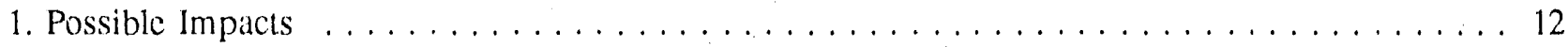

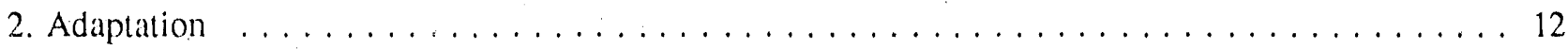

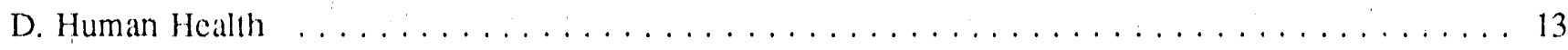

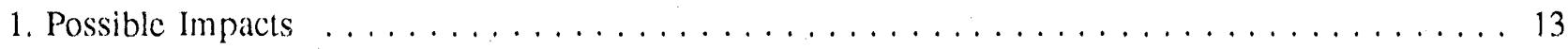

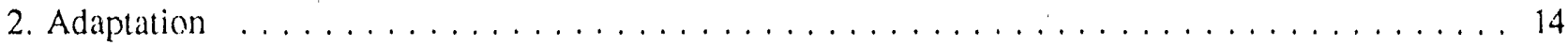

E. Other Potential Effects $\ldots \ldots \ldots \ldots \ldots \ldots \ldots \ldots \ldots \ldots \ldots \ldots \ldots \ldots \ldots \ldots$

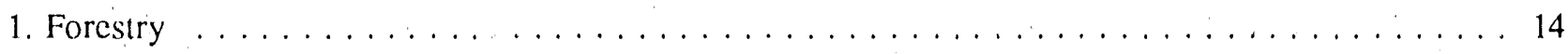

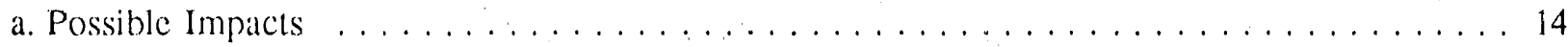

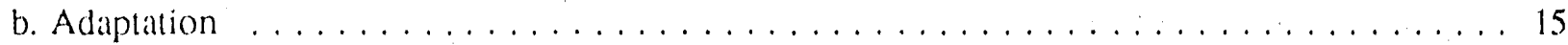

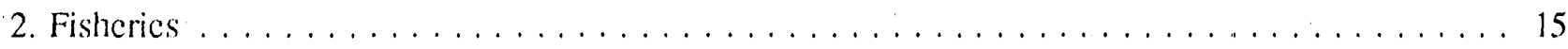

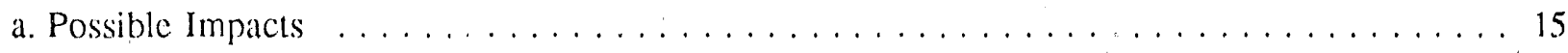

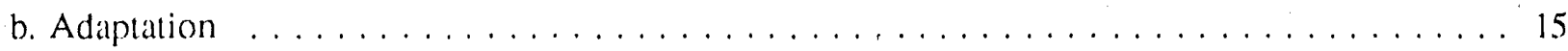

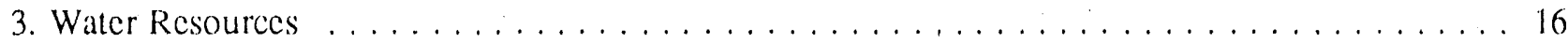

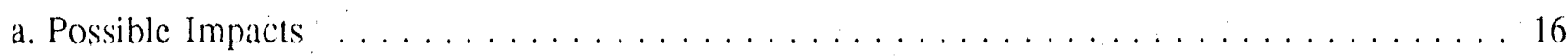

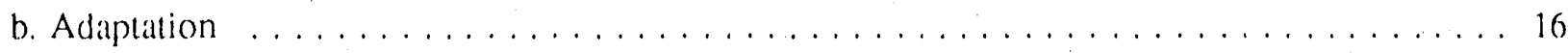




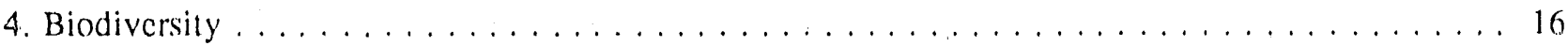

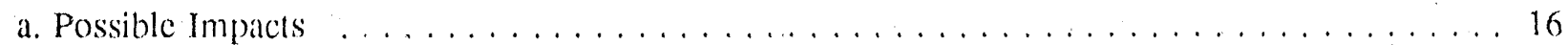

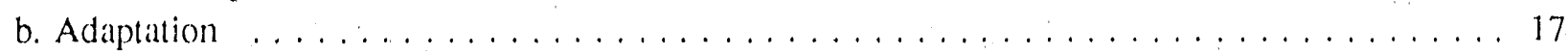

III. Mitigation: Limiting Greenhouse Gas Emissions $\ldots \ldots \ldots \ldots \ldots \ldots \ldots \ldots \ldots \ldots \ldots$

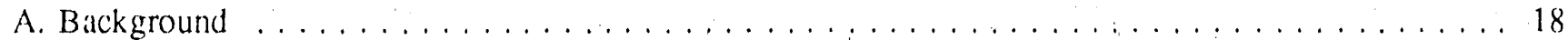

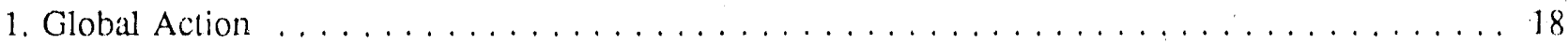

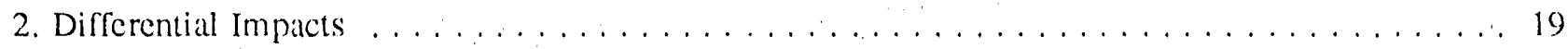

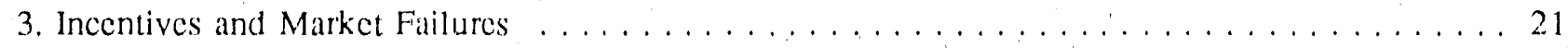

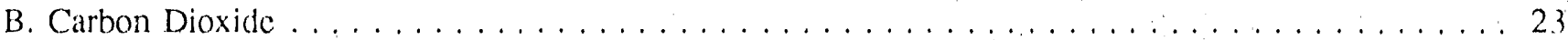

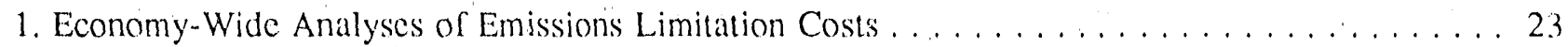

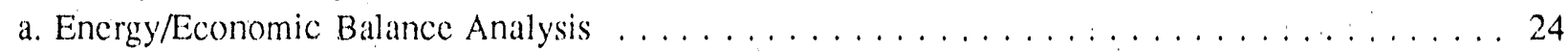

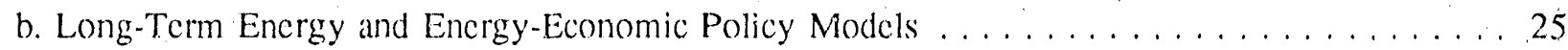

c. Short-Run Economic/Encrgy Models $\ldots \ldots \ldots \ldots \ldots \ldots \ldots \ldots \ldots \ldots \ldots \ldots$

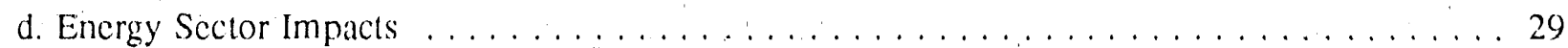

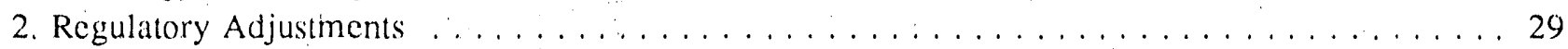

a. Reform of Electric Utility Ratemaking . . . . . . . . . . . . . . . . . . . . . . . 29

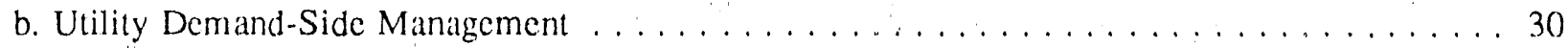

c. Research and Information $\ldots \ldots \ldots \ldots \ldots \ldots \ldots \ldots \ldots \ldots \ldots \ldots \ldots \ldots$. . . . . . . . . . . .

d. Building and Appliance Standards $\ldots \ldots \ldots \ldots \ldots \ldots \ldots \ldots \ldots \ldots \ldots \ldots$

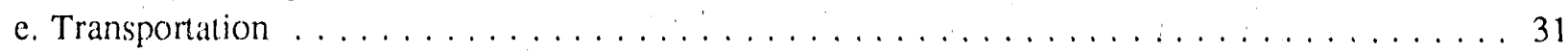

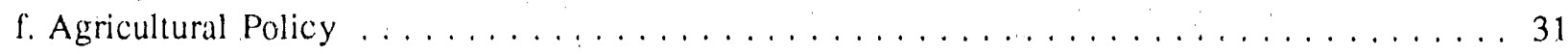

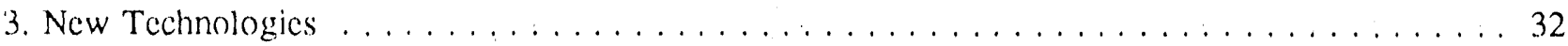

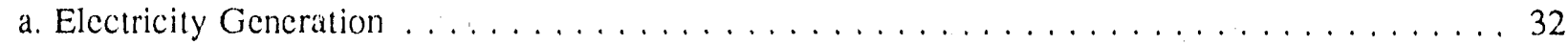

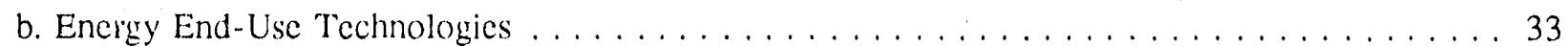

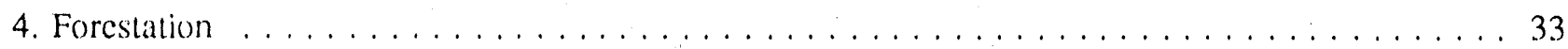

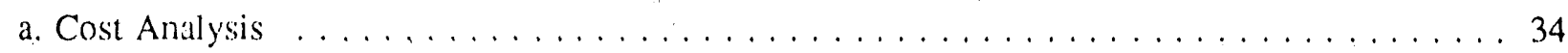

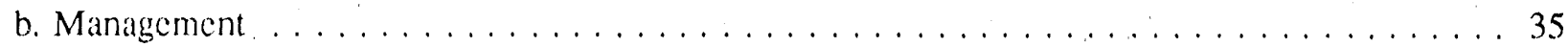

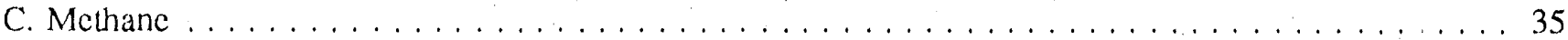

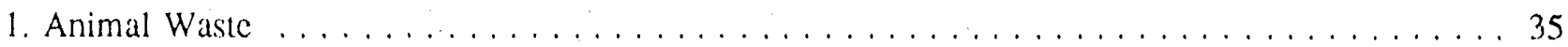

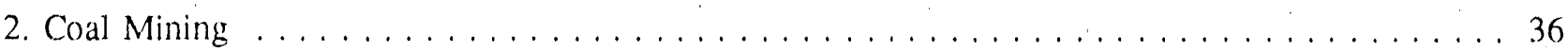

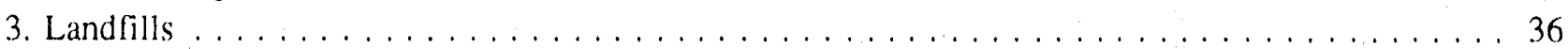

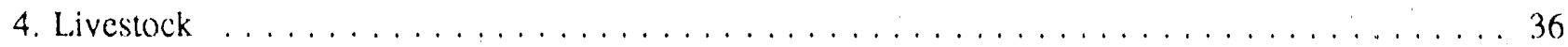

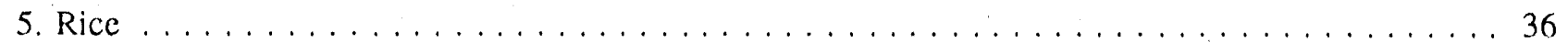

D. Chlorofluorocarbons and Related Substances $\ldots \ldots \ldots \ldots \ldots \ldots \ldots \ldots \ldots \ldots$

E. Nitrous Oxide . . . . . . . . . . . . . . . . . . . . . . . . . . . 37

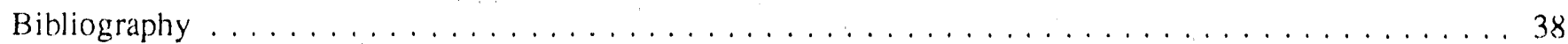




\section{LIST OF TABLES}

I.1 Main Greenhouse Gases $\ldots \ldots \ldots \ldots \ldots \ldots \ldots \ldots \ldots \ldots \ldots \ldots \ldots \ldots \ldots \ldots$

1.2 Carbon Dioxide Anthropogenic Emissions (Percentage Shares) $\ldots \ldots \ldots \ldots \ldots \ldots \ldots \ldots \ldots \ldots$

I.3 Methane Anthropogenic Emissions (Percentage Shares) $\ldots \ldots \ldots \ldots \ldots \ldots \ldots \ldots \ldots$

I.4 Chlorofluorocarbon (CFC-11 + CFC-12)

Emissions (Percentage Shares) $\ldots \ldots \ldots \ldots \ldots \ldots \ldots \ldots \ldots \ldots \ldots \ldots \ldots \ldots \ldots$

I.5 Nitrous Oxide Anthropogenic Emissions (Percentage Shares) $\ldots \ldots \ldots \ldots \ldots \ldots \ldots \ldots \ldots \ldots$

II.1 Estimated Economic Welfare Effects in 2050 of

Climate-Induced Agricultural Yield Changes $\ldots \ldots \ldots \ldots \ldots \ldots \ldots \ldots \ldots$

II.2 Protecting Densely Developed Shoreline

Areas from Sea-Level Rise $\ldots \ldots \ldots \ldots \ldots \ldots \ldots \ldots \ldots \ldots \ldots \ldots \ldots \ldots$

III.1 Anthropogenic Greenhouse Gas Emissions $\ldots \ldots \ldots \ldots \ldots \ldots \ldots \ldots \ldots \ldots \ldots \ldots$

III.2 Global Effects of Unilateral Carbon Dioxide Emissions

Reductions by the United States or the OECD . . . . . . . . . . . . . . . . . . . 19

III.3 OECD Carbon Dioxide Emissions Reductions Required To Achieve

Global Emissions Goals When Other Nations Take Lesser Actions . . . . . . . . . . . . . . . 20

III.4 Carbon Dioxide Emissions Per Capita and Per Dollar of GNP, $1986 \ldots \ldots \ldots \ldots \ldots \ldots$ 


\section{EXECUTIVE SUMMARY}

This report is intended to provide an overview of cconomic issues and research relevant to possible, long-term global climate change. It is primarily a critical survey, not a statement of Administration or Department policy.

There are substantial gaps in current knowledge about the economics and physical science of global climate change. In fact, almost all the quantitative projections in this report, as well as many of the qualitative assertions, are contrr versial. Projections of climate effects and costs in the distant future are inherently less reliable than forecasts of climate and policy costs in the short run.

The Task Force recommends that a coordinated economic research program be undertaken, similar to that in the climate sciences, that would evaluate the economic effects of possible future climate change and the benefits of slowing such change, the costs and effectiveness of various adaptive and emissions reduction measures, and the effects of such measures on U.S. and world trade and capital flows.

The remainder of this Executive Summary provides a brief outline of our main findings. Readers with an interest in a particular topic, such as the impact of possible climate change on agriculture or estimates of the economy-wide impacts of measures to limit carbon dioxide $\left(\mathrm{CO}_{2}\right)$ emissions, should note that the main report, while lengthy, is structured to allow for a selective reading.

\section{Background}

\section{Greenhouse Gas EmIsslons}

Possible climate change is not a one-gas or onc-nation problem. Carbon dioxide, chlorofluorocarbons (CFCs), methane $\left(\mathrm{CH}_{4}\right)$, and nitrous oxide $\left(\mathrm{N}_{2} \mathrm{O}\right)$ have accounted for about 87 percent of the increase in radiative (greenhouse) forcing in the 1980's. Projections of future emissions of these gases are uncertain, and comparisons of the effects of those emissions are not completely straightforward.

Carbon Dioxide. Given the projected expansion in fossil energy use throughout the world, $\mathrm{CO}_{2}$ is expected to account for a larger share of increased radiative forcing in the future than in the past. The United States now accounts for about 21 percent of total anthropogenic $\mathrm{CO}_{2}$ emissions, but that share is expected to shrink to around 12 percent by the middle of the next century.

Methane. Emissions rates of major sources of $\mathrm{CH}_{4}$ are subject to significant uncertainty. Over half of total anthropogenic emissions of methane are produced by domestic animals (enteric fermentation) and rice cultivation. Centrally planned and developing nations account for the bulk of these emissions.

Chlorofluorocarbons. The United States and other developed nations now account for well over half of emissions of CFCs and related gases, but the shares of developing nations are expected to increase sharply as reductions and phascouts are implemented in accord with the Montreal Protocol.

Nitrous Oxide. Most $\mathrm{N}_{2} \mathrm{O}$ emissions are associated with agricultural activity and animal husbandry. Data 
on natural and anthropogenic sources of nitrous oxide emissions are poor.

\section{Scientific Background}

While this report provides a brief discussion of the scientific background to this issue, that discussion should not be interpreted as an attempt to address or evaluate the scientific uncertainties surrounding possible climate change.

Projections of luture emissions of greenhouse gases are highly sensitive to future rates of population growth, economic growth, and development of rew technologies for energy production and use. The inability to place narrow bounds on any of these factors necessarily places very wide bounds on any forecast of future emissions.

Even if future emissions are assumed to be known, considerable uncertainty attaches to the climate changes that would result from increased atmospheric concentration of greenhouse gases. The effects of greenhouse gases on global climate are forecast by climate models, a relatively new tool. Present climate models predict that a doubling of the concentration of carbon dioxide relative to the preindustrial atmosphere-or its equivalent in terms of a combination of greenhouse gases-would result in an eventual global average warming of between $2^{\circ} \mathrm{F}$ and $9^{\circ} \mathrm{F}$. If the atmosphere begins to warm, a transfer of heat from the air to the oceans is expected to slow the rate at which air temperature actually rises. This effect could delay the full impact of any given increase in the concentration of greenhouse gases on observed air temperature for decades or even centuries, with wide variations by region.

Some models suggest a marked soil moisture decrease in mid-latitude continental regions during summer. Global sea-level increases by the year 2050 of 25 to 40 centimeters (a recent estimate of the Intergovernmental Panel on Climate Change, or IPCC) could occur if warming of $2^{\circ} \mathrm{F}$ to $8^{\circ} \mathrm{F}$ occurred by the middle of the next century.
Although the public discussion and most of the initial scientific work has focused on the assessment of changes in mean global surface temperature, many of the impacts of possible climate change considered in this report could be more dependent on other climate variables. Examples of such variables include changes in soil moisture, in summer precipitation or extreme temperature by region, and in the number of days in a row when the temperature exceeds a threshold value important to particular activities or natural processes. A greater focus on these variables will be important in the effort to refine current impact estimates and develop new ones.

\section{Pollcy Alternatives}

Planned adaptation involves actions laken in recognition of anticipated warming to deal with its effects. Unplanned adaptation involves short-run responses to actual warming as it takes place. Mitigation policies are aimed at reducing the rate of possible warming by reducing net emissions of greenhouse gases. Mitigation policies must generally be implemented well before adaptation policies. They must also be implemented on a global scale. The important economic implications of differences in timing between adaptation and mitigation costs can only be revealed by discounting.

Most studies of impacts and adaptation costs considered in this report provide estimates for at most a small set of climate change scenarios. Differences in methods and assumptions preclude addition of costs across studies. Impacts and costs are almost always estimated relative to a baseline of no climate change. Such estimates necessarily overstate the reductions in impacts and adaptation costs associated with mitigation strategies, such as those considered in this report, that do not stabilize atmospheric concentrations of greenhouse gases and thus, under the assumptions of current climate models, do not forestall climate change entircly.

Given that the implications of global warming are still unclear, additional research is certainly called for. Uncertainty also increases the attractiveness of 
relatively inexpensive, flexible policies that can easily be reversed or expanded, and policies that can be justified for reasons other than climate change.

\section{Adaptation: Living With Global Warming}

\section{Climate and the Economy}

The direct economic effects of climate change would be concentrated primarily in agriculture, forestry, and possibly fisheries, which currently account for about 2 percent of U.S. gross domestic product (GDP) and about 5 percent of world GDP. In addition, a rise in the sea level coulci inundate valuable dry land. Apart from agriculture and sea-level rise, little quantitative research on climate impacts or adaptation costs has been done.

The indirect cffects of climate change will create winners and losers throughout the United States and global economies as demand shifts occur. For example, demand for air conditioners and summertime electricity could rise, while demand for space heating equipment and fuels and could fall. Tourism might also be affected. The costs of adaptation would depend critically on how rapidly warming occurs relative to the economic lifelimes of major immobile assets.

\section{Agriculture}

Climate change could affect agricultural yields both positively and negatively through variations in regional temperature, seasonality, precipitation, and soil moisture. Estimates of these effects are very uncertain. While increased $\mathrm{CO}_{2}$ concentrations alone would likely have a direct positive effect on efficiency of photosynthesis and water use, the effects of higher temperatures could reduce yields. Estimates of the impact of future global change on U.S. cereal crop yields range from an increase of 10 to 15 percent to a decrease of about the same magnitude.

Net economic effects on any country's agricultural sector depend on global yields and consequent impacts on market prices and trade flows as well as on regional yield effects. Analysis by the U.S. Department of
Agriculture of a scenario in which the U.S. grain and oilseed crop yields decrease by between 10 and 15 percent shows slightly increased overall U.S. welfare once the effects of increased export prices are factored into the analysis. This analysis suggests that climate-induced changes in agriculture would not produce major positive or negative economic effects by the middle of the next century. Yet, there could be significant regional dislocations in crop production.

\section{Sea-Level Changes}

The adverse effects of possible sea-level rise on coastal infrastructure, recreation, and coastal ccology could be either large or small, depending on the rate and magnitude of any sea-level rise and on the extent of planned adaptation. While densely developed shoreline areas in the United States could be protected against sea-level rises that might occur by 2050 for less than $\$ 10$ billion (present value), significant net losses of drylands and wetlands could occur.

\section{Human Health}

The impacts of a possible warming on human health are extremely controversial, and the scope for planned adaptation is unclear. Some studies show significant possible increases in heat-related deaths, while others argue that cities with appreciably different climates show no climate-related differences in health risk. Global warming would likely cause some vector-borne tropical discases to spread northward, but the magnitude of this problem is unclear On the other hand, there could be a decline in cols-related deaths.

\section{Other Potential Effects}

Forestry. If significant warming occurs, changes in U.S. forests could be apparent in 30 to 80 years. Significant changes in forest range are possible. Changes in forest distribution and composition could have major impacts on timber production, runoff from forests, and recreational opportunities. Without human intervention, rapid warming could move natural habitats of mid- and high-latitude forests poleward faster than natural rates of ferest migration could accommodate. Today's forest management decisions 
could have lohg-term impacts on the composition and location of forests.

Fisheries. Fishery resources are known to be sensitive to climate variation. However, the qualitative effects of warming on lisheries are highly uncertain, and no quantitative economic analysis has, to our knowledge, been attempted. Absent human intervention, ocean species are likely to be less affected by any climate change than freshwater species, since oceans would respond to atmospheric warming more slowly than smaller bodies of water. Both the need and the opportunity for planned adaptation in the commercial fishing sector appears to be limited.

Water Resources. In general, it is difficult to predict the impacts of climate change on water resources with confidence because of uncertainties about regional precipitation. If significantly higher temperatures occur, water supplies in California and the lower Great Lakes could be reduced.

Biodiversity. The impacts of climate change on natural communities are difficult to predict. Possible global warming could result in a decline in biodiversity stemming from the loss or change of habitats that result in the decline or loss of some animal and plant species.

\section{Mitigation: Limiting Greenhouse Gas Emissions}

The costs of reducing carbon dioxide and CFC emissions are under active study. Available estimates of $\mathrm{CO}_{2}$ abatement costs remain preliminary and controversial. Relatively little is known about the costs of reducing cmissions of other greenhouse gases. A revision of this section of the report a year or two from now could rely on a much stronger research base (particularly as regards $\mathrm{CO}_{2}$ ) and might well have different policy implications.

\section{Background}

Global Action and Differentiall Impacts. Global action is essential if meaningful reductions in the expected growth of any of the greenhouse gases are to be obtained without bringing economic growth to a halt. Even dramatic unilateral cuts by member stales of the Organization for Economic Cooperation and Development (OECD) would not be sufficient to achieve widely discussed global $\mathrm{CO}_{2}$ cmissions goals unless most other countries participate fully in emissions reduction efforts. For example, even the total climination of $\mathrm{CCD}$ emissions over the next 15 years would be insufficient to obtain a 20-percent global emissions reduction by 2005 if the USSR and Eastern Europe only stabilize emissions at their current levels and developing countries take no action to curb $\mathrm{CO}_{2}$ emissions growth. Global action would also be necessary to control methane and nitrous oxide cmissions, which result primarily from agricultural and energy activities.

Differences in costs and benefits among nations may make it difficult to obtain global agreement on specific goals and policies. For example, countries planning to rely heavily on coal, which contains a relatively high amount of carbon per unit of energy, may have greater $\mathrm{CO}_{2}$ emissions than countries planning to rely more on nuclear energy. These issues will have important implications for energy security and trade balances.

Incentives and Market Failures. An approach to limiting net anthropogenic greenhouse emissions that encompasses all important greenhouse gases and gas sinks as well as gas sources is preferable to one that considers each source of greenhouse gases individually. Also, ar.y set of nations should be free to develop a joint strategy to meet their pooled ceilings, as long as net global emissions are not thercby increased and existing treaty obligations are not thereby violated. An approach incorporating these elements was outlined in a U.S. concept paper introduced at the IPCC.

All analysts agree that some reductions in greenhouse gas emissions can be obtained at low cost. The phaseout in CFCs recently agreed to at the June 1990 meeting of the parties to the Montreal Protocol falls into this category. Current research has not been sufficient to detail the extert of low-cost opportunities for limiting other greenhouse gases.

Command-and-control efficiency standards have several significant disadvantages in comp"rison to incentive-based systems-- such as charges, user fees, 
and tradable emissions rights-or approaches that address perceived market failures directly. When market failures limit the power of such approaches, those failures can be addressed directly. The costs of efficiency standards are often hidden rather than explicit.

\section{Carbon Dloxlde}

Economy-Wide Analyses of Emission Limitation Costs. Several studies of carbon dioxide reduction costs using economy-wide moriels have recently been completed or are now in progress. These papers use a variety of modeling approaches, consider different poicies, and employ different baseline emissions growth assumptions. These differences have important effects on cost estimates. All these results must be considered preliminary.

In general, work to date finds that the costs of stabilization or reduction of $\mathrm{CO}_{2}$ emissions by 2005 will be high-at least 1 percent of the gross national product (GNP) per year for widely discussed objectives, such as stabilizing $\mathrm{CO}_{2}$ emissions at the present level or securing and maintaining a 20-percent reduction from that level. Some estimates suggest that achievement of such objectives would involve significant reductions in long-term growth. During the 1973-85 oil shock period, $\mathrm{CO}_{2}$ emissions were constant but economic growth was slow. This experience offers a useful reference for comparison of likely impacts of policies to curtail fossil energy use sharply on output and productivity growth.

Some recent analyses consider the use of a charge on the carbon content of fossil fuels to reduce $\mathrm{CO}_{2}$ emissions. This research generally concludes that charges on the order of $\$ 100$ per ton (which would amount to roughly a 180-percent increase in the delivered price of coal and a 70-percent increase in the price of oil) would be needed to have a significant effect on ernissions. Much lower carbon charges may be of some value in the near term to compensate for known extemal effects of energy use, to test the sensitivity of $\mathrm{CO}_{2}$ emissions to incentives, and to lay the foundations for higher future charges if they are found necessary.

The aggregatc economic effects of $\mathrm{CO}_{2}$ emissions reduction policies would not be felt evenly throughout the U.S. economy. The relative cost of energy would increase substantially, increasing the relative price and decreasing the consumption of energy-intensive products. It is impossible to construct a scenario for substantial $\mathrm{CO}_{2}$ emissions reduction without a major adverse impact on the coal industry. General equilibrium modeling suggests that an effort to limit $\mathrm{CO}_{2}$ emissions significantly would cause large changes in the sectoral composition of the U.S. economy. Such sectoral changes, if gradual, might occur without a drastic impact on the value of existing assets. However, a policy that resulted in rapid sectoral changes could have a significant impact on the value of assets in impacted industries and on the value of immobile assets, such as residential housing, in impacted communities.

Because the United States relies heavily on coal (the fossil fuel with the highest amount of carbon per unit of energy) for electricity generation, U.S. electricity rates would be likely to rise more than those in other industrialized countries if concerted action were taken to curb $\mathrm{CO}_{2}$ emissions. Unless energy-intensive U.S. industries were able to increase their encrgy efficiency, they could be disadvantaged relative to major foreign competitors who would be less affected by electricity rate increases.

Regulatory Adjustments. There are a number of reasons why total U.S. investment in energy efficiency may be suboptimal. Many analysts have called for a variety of regulatory initiatives to increase the efficiency of energy use and, thereby, to reduce $\mathrm{CO}_{2}$ emissions.

The climination of electricity pricing distortions would be as likely to yicld increases in consumption and emissions as decreases. Many analysts have called for reform of electric and gas utility regulation to give utilities incentives to remove impediments to efficient investment in energy conservation. While the desirability of regulatory changes of these sorts is apparent, estimates of potential reductions in $\mathrm{CO}_{2}$ emissions vary widely.

Encrgy-efficiency standards for buildings, appliances, and automobiles represent another approach to limiting energy consumption, and thus $\mathrm{CO}_{2}$ emissions. However, any information problems, institutional 
rigidities, or market failures that may exist can be addressed directly, rather than through efficiency standards that can impose significart hidden costs on consumers and the economy at large.

A number of changes in agricultural programs that would have other benefits can be expected to assist in reducing greenhouse gas emissions. These include reducing commodity price support levels, encouraging addicional tree planting, and expanding conservation programs.

New Technologies. While new technologies offer significant $\mathrm{CO}_{2}$ emissions reduction potential after the year 2000, there is no simple "technological fix" to this problem. A variety of technologies for generating electricity are in various stages of development. The next generation of nuclear reactors, based on simplified and standardized designs and passive safety features, may come into use after the year 2000. Advanced energy-use technology seems to have the potential to contribute signilicantly to reducing $\mathrm{CO}_{2}$ emissions, but estimates of the extent of the contribution vary widely.

Increases in research and development budgets for end-user energy-efficiency improvements and for programs that provide financial and technical assistance to States, both of which have declined in recent years, would enhance conservation efforts. Most studies have found that the potential gains from widespread use of available "best practice" technology are significant, possibly up to 15 percent of current consumption.

Forestation. Reforestation is a (comparatively) short-term approdch that could generate a substantial decrease in net $\mathrm{CO}_{2}$ emissions for at least three to five decades. Cost estimates in one study of a global strategy ranged from $\$ 4.29$ to $\$ 8.03$ per metric ton of carbon removed, while those in another study for the United States ranged from $\$ 17.71$ to $\$ 102.63$ per metric ton depending on program size. The net ecological and recreational benefits of forestation would depend on the type of forest planted and the current use of the land. The efficacy of forestation as a carbon managemerit tool depends importantly on how the stock of accumulated carbon in mature forests is managed, but the costs and carbon removal potential of alternative management strategies have not been systematically analyzed.

\section{Methane}

Because the developed countries account for only about 25 percent of anthropogenic methane emissions, significant, cost-effective reductions in $\mathrm{CH}_{4}$ emissions will require giobal action. Feasible reductions in the areas of animal waste, sizes of livestock herds, coal mining, natural gas production, transmission, and distribution, landfills, and livestock and rice production add up to more than enough to stabilize atmospheric $\mathrm{CH}_{4}$ concentrations. While a number of approaches to controlling these ernissions are available, no systematic policy design or costing analysis has been performed.

\section{Chlorofluorocarborts}

The Montreal Protocol has been ratified by nations that account for over 90 percent of global consumption. The Protocol was renegotiated in June 1990 and now provides for a phaseout of all CFCs by the year 2000 . With widespread participation, this phaseout will significantly reduce the increase in radiative forcing attributable to greenhouse gas emissions during the next century. The costs of eliminating the use of CFCs in the United States will be approximately $\$ 3$ billion (present value) over the next 10 years.

\section{Nitrous Oxide}

No systematic attention seems to have been devoted to the design or cost of policies to reduce $\mathrm{N}_{2} \mathrm{O}$ emissions from fertilizer use or other sources, in part because the relevant science base is weak. The relationship of $\mathrm{N}_{2} \mathrm{O}$ emissions to energy production and use have been questioned by recent research findings. Resolution of uncertainty in this area is a high priority. 


\section{INTRODUCTION}

Work on this report began in the fall of 1989 , when an interagency task force was instructed to "identify, review, and inventory" work on the economics of climate change in order to inform policy discussions. (The task force included representatives from the Council of Economic Advisors; the Departments of State, Treasury, Commerce, Interior, Agriculture, and Energy; the Environmental Protection Agency; the Office of Management and Budget; and the Office of Science and Technology Policy.) A preliminary report was presented in March, 1990. The present document represents a refinement and limited updating of that report. It is intended to provide an overvie's of current knowledge and key facts and is not a statement of Administration or Department policy.

This report should serve to indicate that economic analysis of global change is in its infancy; few asserions about costs or benefits can be made with confidence. The state of the literature precludes any attempt to produce anything like a comprehensive benefit-cost analysis. (But see Nordhaus (1990a) for a crude but interesting attempt.) Morcover, almost all the quantitative estimates regarding physical and econornic effects in this report, as well as many of the qualitative assertions, are controversial.

Section I provides background on greenhouse gas emissions and their likely climatic effects and on available policy instruments. Section II considers the costs of living with global change, assuming no substantial efforts to reduce greenhouse gas emissions. Scction III considers costs of reducing those emissions, though the available literature does not contain estimates of the costs of policies that would, on the assumptions of current climate models, prevent climate change altogether. The individual sections are not entirely compartmentalized, but can be read independently if necessary. 


\section{BACKGROUND}

This section provides background material on current and projected future greenhouse emissions and on scientific opinion regarding the effects of those emissions on the global climate. The final subsection provides a brief, general discussion of adaptation and mitigation strategies, which serves as an introduction to the analysis of these strategies in Sections II and III, respectively.

\section{A. Greenhouse Gas Emissions}

Increases in the atmospheric concentrations of at least 25 trace gases contribute directly or (via chemical reactions) indirectly to the retention of solar radiation by the earth (radiative forcing). Five greenhouse gases, described in Table I.1, have accounted for about 87 percent of the increase in radiative forcing in the 1980s and about 92 percent of the increase over the 1880-1980 period (Ramanathan, et al., 1985; Hansen, et al., 1988). These gases are, accordingly, the focus of the rest of this subsection and of the mitigation strategies considered in Section III. The emissions projections for these gases in Tables 1.2 to 1.5 are based on the Rapidly Changing World scenario in Lashof and Tirpak (1989); they should be treated as providing rough orders of magnitude, not precise estimates.

Comparisons of the effects of future emissions of various greenhouse gases are not completely straightforward. Differences in atmospheric lifetimes lead to different time patterns of effects, so that decisions regarding discounting may be important (Lashof and Ahuja, 1989). (Note also the uncertainty attached to the lifetime of nitrous oxide $\left(\mathrm{N}_{2} \mathrm{O}\right)$.) And, while the radiative forcing effects of changes in atmospheric concentrations of any trace gas are apparently easy to calculate, the effects of changes in

\section{Table I.1 - Maln Greenhouse Gases}

\begin{tabular}{lccc}
\hline Gas & $\begin{array}{c}\text { Percentage Share } \\
\text { of Increased } \\
\text { Radiative Forcing } \\
\text { in the 1980s }\end{array}$ & $\begin{array}{c}\text { Atmospheric } \\
\text { Lifetime } \\
\text { (years) }\end{array}$ & $\begin{array}{c}\text { Forcing } \\
\text { Index } \\
\text { (molecular) }\end{array}$ \\
\hline Carbon Dioxide $\left(\mathrm{CO}_{2}\right)$ & 49 & 250 & 1 \\
Methane $\left(\mathrm{CH}_{4}\right)$ & 19 & 10 & 30 \\
Chlorofluorocarbons & 14 & $60 \& 75$ & $22,(000 \&$ \\
$(\mathrm{CFC}-11 \&(\mathrm{FC}-12)$ & 5 & $100-175$ & $25,000)$ \\
Nituous Oxide $\left(\mathrm{N}_{2} \mathrm{O}\right)$ & & & 200 \\
\hline
\end{tabular}

Sources: Hansen, et al. (1988); Department of Energy; Wuebbles and Edmonds (1988). 
emissions on atmospheric concentrations depend both on preexisting concentrations and on various imperfectly understood geophysical feedbacks, which also affect atmospheric lifetimes.

\section{Carbon Dloxide}

Measurements of carbon dioxide $\left(\mathrm{CO}_{2}\right)$ levels show atmospheric concentrations increasing from somewhere between 250 and 295 parts per million (ppm) at the beginning of the 19th century to $346 \mathrm{ppm}$ in 1986 . Good data are available on fossil fuel $\mathrm{CO}_{2}$ emissions and (the far smaller) emissions from cement production; data on the impacts of land-use changes (primarily tropical dcforestation) are fair to poor. It is important to keer in mind that natural flows of carbon into and out of the atmosphere are roughly ten to twenty times larger than the (anthropogenic) flows associated with human activity.
Table 1.2 provides historical and projected anthropogenic emissions data by region and by source assuming no mitigation. These projections are uncertain because of uncertainties about future population and economic growth, sectoral composition of gross national product (GNP), and sector-specific energy efficiencies. Nonetheless, it is important to note that because energy-related sources of $\mathrm{CO}_{2}$ emissions are expected to grow comparatively rapidly, and chlorofluorocarbons (CFCs) are expected to be controlled significantly, $\mathrm{CO}_{2}$ is expected to account for a larger share of increased radiative forcing in the future than in the past.

The U.S. now accounts for about 21 percent of total anthropogenic $\mathrm{CO}_{2}$ emissions, but that share is expected to shrink to around 12 percent by the middle of the next century. Despite the attention paid to

Table I.2 - Carbon Dioxide Anthropogenic EmIssions (Percentage Shares)

\begin{tabular}{|c|c|c|c|c|}
\hline \multirow[b]{2}{*}{ Source } & \multirow[b]{2}{*}{1985} & \multicolumn{3}{|c|}{ Projections } \\
\hline & & 2000 & 2015 & 2050 \\
\hline \multicolumn{5}{|l|}{ Countries } \\
\hline United States & 21 & 19 & 16 & 12 \\
\hline Rest of OECD & 22 & 19 & 16 & 12 \\
\hline SSR \& Eastern Europe & 22 & 22 & 19 & 18 \\
\hline Centrally Planned Asia & 10 & 13 & 161 & \\
\hline \multirow[t]{2}{*}{ Other Developing } & 25 & 28 & 32 & 37 \\
\hline & $\overline{100}$ & $\overline{100}$ & 100 & $\overline{100}$ \\
\hline \multicolumn{5}{|l|}{ Sectors } \\
\hline Commercial Energy & 86 & 87 & 89 & 92 \\
\hline Tropical Def( restation & 12 & 11 & 9 & 6 \\
\hline \multirow[t]{2}{*}{ Other } & $\underline{2}$ & $\underline{2}$ & $\underline{2}$ & $\underline{2}$ \\
\hline & 100 & $\overline{100}$ & $\overline{100}$ & $\overline{100}$ \\
\hline $\begin{array}{l}\text { Total Scenario Emissions } \\
\left(10^{9} \text { metric tons of carbon) }\right.\end{array}$ & 5.99 & 8.05 & 10.27 & 16.95 \\
\hline Average Annual Growth Rate & & & & \\
\hline
\end{tabular}

Source: USEPA (1989) Rapidly Changing World Scenario 
tropicai deforestation, most anthropogenic $\mathrm{CO}_{2}$ emissions are and will be the result of combustion of fossil fuels. The United States has comparatively high $\mathrm{CO}_{2}$ emissions per capita from fossil fuel consumption and cement production, in part because it makes relatively heavy use of coal. In the United States, coal burned by electric utilities accounts for 31 percent of total fossil fuel $\mathrm{CO}_{2}$ emissions; the entire utility sector accounts for 37 percent, and the transportation and industrial sectors account for 29 and 21 percent, respectively.

\section{Methane}

Atmospheric concentrations of methane $\left(\mathrm{CH}_{4}\right)$ were relatively constant prior to the middle of the last century at about 700 parts per billion (ppb); by 1987
$\mathrm{CH}_{4}$ concentrations had increased to $1,675 \mathrm{ppb}$. Recently, atmospheric concentrations of methane have been increasing at an observed rate of about 1.1 percent annually. The contributions of the different sources of methane that together account for aggregate emissions remain uncertain. Anthropogenic emissions of $\mathrm{CH}_{4}$ are thought to account for roughly two-thirds of all emissions. Table 1.3 contains estimates of anthropogenic emissions; they should be treated as uncertain.

The i.nited States now contributes about 12 percent of anthropogenic emissions of $\mathrm{CH}_{4}$; this share is predicted to decline to about 8 percent. Over half of total anthropogenic emissions of methane are produced by domestic animals (enteric fermentation) and rice

Table 1.3 - Methane Anthropogenic Emissions (Percentage Shares)

\begin{tabular}{|c|c|c|c|c|}
\hline \multirow[b]{2}{*}{ Source } & \multirow[b]{2}{*}{1985} & \multicolumn{3}{|c|}{ Projections } \\
\hline & & 2000 & 2015 & 2050 \\
\hline \multicolumn{5}{|l|}{ Countries } \\
\hline United States & 12 & 11 & 9 & 8 \\
\hline Rest of OECD & 13 & 12 & 12 & 10 \\
\hline USSR \& Eastern Europe & 13 & 14 & 14 & 15 \\
\hline Centrally Planned Asia & 17 & 16 & 17 & 19 \\
\hline \multirow[t]{2}{*}{ Other Devcloping } & 46 & 47 & 49 & 48 \\
\hline & $\overline{100}$ & $\overline{100}$ & $\overline{100}$ & $\overline{100}$ \\
\hline \multicolumn{5}{|l|}{ Sectors } \\
\hline Fuel Production & 18 & 22 & 26 & 32 \\
\hline Enteric Fermentation & 23 & 24 & 23 & 22 \\
\hline Rice Cultivation & 34 & 31 & 29 & 24 \\
\hline Landfills & 9 & 10 & 10 & 14 \\
\hline Tropical Deforestation & 6 & 6 & 5 & 4 \\
\hline \multirow[t]{2}{*}{ Other } & $\frac{9}{00}$ & $\frac{7}{100}$ & $\frac{7}{100}$ & $\frac{5}{100}$ \\
\hline & 100 & 100 & 100 & $\overline{100}$ \\
\hline $\begin{array}{l}\text { Total Scenario Emissions } \\
\left(10^{6} \text { metric tons of } \mathrm{CH}_{4}\right)\end{array}$ & 320.1 & 399.5 & 476.8 & 710.5 \\
\hline Average Annual Growth Rate & & & & \\
\hline
\end{tabular}

Source: USEPA (1989) Rapidly Changing World Scenario 
cultivation. The centrally planned and developing nations account for the bulk of these methane emissions. Energy-related methane emissions occur in coal mining, and when natural gas is gathered, transmitted, distributed or vented.

\section{Chlorofluorocarbons}

CFCs are entirely man-made and were invented during the 20th cenlury. The concentrations of CFC-11 and CFC-12 were 226 parts per trillion (ppl) and $392 \mathrm{ppt}$, respectively, in 1986 and have been rising at 4 percent annually. Table $\mathrm{I} .4$ gives projected regional emissions of these two gases assuming implementation of the Montreal Protocol (aimed at reducing stratospheric ozone depletion) as it existed prior to June, 1990, with 100 percent participation by developed countries and 75 percent participation elsewhere. In June 1990, the parties agreed to a total phaseout of CFCs by the year 2000 in place of the 50-percent emissions reduction reflected in Table 1.4 .
Note that global emissions of CFC-11 and CFC-12 were projected to increase under the terms of the Montral Protocol as they existed prior to the June 1990 revision. Emissions of related greenhouse gases (particularly CFC-22 and methyl chloroform) were also projected to increase quite rapidly, but the revised Protocol now covers some of these gases; for example, methyl chloroform, which had earlier been expected to see increasing use, is now to be phased out by 2005 . Considering these related gases does not alter the messagc of Table 1.4: the United States and other developed nations now account for well over half of emissions of CFCs and related gases, but, even under the original terms of the Montreal Protocol, the shares of developing nations would have been expected to increase sharply. The recent revisions to the Protocol will reduce the emissions of signatory rations by a substantial further amount. The extent of developing country participation in the phaseout of CFCs is uncertain and will significantly affect future shares and quantities of emissions.

Table 1.4 - Chlorofluorocarbon (CFC-11 + CFC-12) Emlssions (Percentage Shares) Assuming No Further Conirols Beyond Origina! Montreal Protocol

\begin{tabular}{|c|c|c|c|c|}
\hline \multirow[b]{2}{*}{ Source } & \multirow[b]{2}{*}{1985} & \multicolumn{3}{|c|}{ Projections } \\
\hline & & 2000 & 2015 & 2050 \\
\hline United States & 24 & 18 & 17 & 12 \\
\hline Other Devcloped & 41 & 24 & 24 & 21 \\
\hline USSR \& Eastern Europe & 16 & 14 & 14 & 13 \\
\hline $0.2 \mathrm{Kg}$ Nations* & 6 & 14 & 15 & 19 \\
\hline Other Developing & $\frac{12}{100}$ & $\frac{30}{100}$ & 30 & 36 \\
\hline & 100 & 100 & $\overline{100}$ & $\overline{100}$ \\
\hline $\begin{array}{l}\text { Total Scenario Emissions } \\
\left(10^{3} \text { tonnes } \mathrm{CFC}\right)\end{array}$ & 642.1 & 837.8 & 755.1 & 828.5 \\
\hline Average Annual Growth Rate & \multicolumn{4}{|c|}{$0.4 \%$} \\
\hline
\end{tabular}

*Nations with CFC usc: betwece 0.1 and 0.2 kilograms per capita and likely to reach the 0.3 kilogram per capita limit in the Montreal Irolusis i prior to 1999.

Source: USEPA 


\section{Nitrous Oxide}

Atmospheric concentrations of $\mathrm{N}_{2} \mathrm{O}$ averaged about 285 ppb from 1600 to 1800 , began to rise slowly at the start of this century and more rapidly after 1940, and are now around $310 \mathrm{ppb}$. Data on natural and anthropogenic sources of $\mathrm{N}_{2} \mathrm{O}$ emissions are poor, and the data in Table 1.5 should be considered as approximate at best. The Department of Energy believes that $\mathrm{N}_{2} \mathrm{O}$ emissions associated with energy processes may be overestimated by an order of magnitude.

As in the case of methane, most $\mathrm{N}_{2} \mathrm{O}$ emissions are associated with agricultural activity and with developing nations. Increased fertilizer use has both raised $\mathrm{N}_{2} \mathrm{O}$ emissions and dramatically increased food supplies in many developing nations. The U.S. share of world $\mathrm{N}_{2} \mathrm{O}$ emissions is only about 14 percent and is expected to fall below 10 percent by mid-century.

\section{B. Potential Climate Changes}

Formulating a realistic and responsible outlook on possible climate effects associated with increasing atmospheric greenhouse gas concentrations requires providing answers to a sequence of increasingly complex questions.

\section{Uncertainties}

It is first necessary to project future emissions of grecnhouse gases. As noted above, such projections are inevitably quite uncertain. Economics research has an

Table 1.5 - Nitrous Oxide Anthropogenic Emissions (Percentage Shares)

\begin{tabular}{|c|c|c|c|c|}
\hline \multirow[b]{2}{*}{ Source } & \multirow[b]{2}{*}{$198 j$} & \multicolumn{3}{|c|}{ Projections } \\
\hline & & 2000 & 2015 & 2050 \\
\hline \multicolumn{5}{|l|}{ Countries } \\
\hline United States & 14 & 12 & 11 & 9 \\
\hline Rest of OECD & 13 & 14 & 14 & 12 \\
\hline USSR \& Eastern Europe & 14 & 15 & 14 & 13 \\
\hline Centrally Planned Asia & 13 & 16 & 14 & 15 \\
\hline \multirow[t]{2}{*}{ Other Developing } & 46 & 47 & 47 & $\underline{52}$ \\
\hline & $\overline{100}$ & 100 & $\overline{100}$ & $\overline{100}$ \\
\hline \multicolumn{5}{|l|}{ Sectors } \\
\hline Coal Combustion & 25 & 26 & 29 & 36 \\
\hline Fertilizer Use & 38 & 43 & 44 & 41 \\
\hline Gain of Cultivated Land & 10) & 8 & 8 & 6 \\
\hline Tropical Deforestation & 13 & 11 & 10 & 9 \\
\hline Fuelwood \& Ind. Biomass & 5 & 4 & 3 & 2 \\
\hline \multirow[t]{2}{*}{ Agricultural Wastes } & 10 & 8 & 7 & 6 \\
\hline & $\overline{100}$ & $\overline{100}$ & $\overline{100}$ & $\overline{1\left(x^{\prime}\right)}$ \\
\hline $\begin{array}{l}\text { Total Scenario Emissions } \\
\left(10^{6} \text { tonnes } \mathrm{N}_{2} \mathrm{O}\right)\end{array}$ & 4.21 & 5.85 & 6.87 & 8.85 \\
\hline Average Annual Growth Rate & \multicolumn{4}{|c|}{$1.2 \%$} \\
\hline
\end{tabular}

Source: USEPA 
important role to play in refining emissions forecasts. It is then necessary to predict how much of the assumed emissions will remain in the atmosphere after accounting for the effects of natural processes. Typicai tentative scenarios, like those underlying the projections of emissions shares in Tables 1.2 to 1.5 , assume that emissions will be sufficient to result in the radiative equivalent of a doubling of atmospheric carbon dioxide (the combined effects of $\mathrm{CO}_{2}$ and other trace gas increases) between 2030 and 2070.

Once the greenhouse gas levels in the atmosphere are projected, the next step is to project associated changes in heating of the earth system as a whole. Such projections are highly sensitive to the treatment of feedback mechanisms that can either reduce or amplify the effects of a greenhouse gas buildup. Potentially important positive and negative feedbacks which are not fully understood are an important additional source of uncertainty in projections of earth system warming. For example, the role of clouds is still in dispute.

The next question is more subtle and complex: At what rate is the observed mean global surface temperature likely to change? The role of the ocean as a heat sink is a key element in the linkage between earth system warming and global surface warming. Recent computations with one of the world's lcading coupled ocean/atmosphere models indicate that a 1-percent-peryear carbon dioxide buildup (doubling by 2040; redoubling by 2120 ) would produce a warming of $3.8^{\circ} \mathrm{F}$ at the equator by 2050 , increasing to around $7.2^{\circ} \mathrm{F}$ at high northern latitudes. But in this computation, the southem latitudes hardly warm at all because the high-latitude southern ocean absorbs virtually all the heat from greenhouse warming (ocean temperatures increase slightly). Under this model, the carth system would clearly warm, but air temperatures would scarcely be affected in the Southern Hemisphere. The particular configuration of the ocean, atmosphere, and land surface in the Southern Hemisphere is responsible for this outcome. More generally, observed increases in air temperatures will lag behind equilibrium temperature increases (those that would eventually occur with given atmospheric concentrations of greenhouse gases) for decades or even centuries.

\section{Projections}

Because of these multiple, compounding uncertainties, quantitative model projections of greenhouse gas warming are subject to change as understanding progresses. All current climate models predict that doubling the concentration of $\mathrm{CO}_{2}$ relative to the preindustrial atmosphere would result in an eventual global average warming. Present quantitative predictions for actual (realized) avcrage warming by 2050 vary over the range of $2^{\circ} \mathrm{F}$ to $8^{\circ} \mathrm{F}$. (The low (high) end of this range corresponds roughly to the annual average difference between Washington, D.C. and Sacramento (Dallas).) However, some recent results from models using specifications of cloud behavior believed to be more realistic have reduced equilibrium warming projections by half. Modelers generally agree that seasonality will decrease, with winter temperatures rising more than summer ones.

Possible changes in worldwide sea level are also subject to considerable uncertainty. Warming could raise sea level by thermal expansion of the upper layers of the ocean and by the melting of land-based ice. However, recent measurements have found that Greenland and Antarctic ice cover is currently increasing, not melting away. An American Geophysical Union panel recently suggested a range of global sea-level increases by 2050 of between 10 and 70 centimeters. The present consensus within the science group of the Intergovernmental Pancl on Climate Change (IPCC) is that a warming within the range projected by climate models might be accompanied by a global sea-level rise of between 25 and 40 centimeters by 2050.

While the public discussion and most of the initial scientific work has focused on the assessment of changes in mean global surface temperature, many of the economic impacts considered in this report could be more dependent on other climate variables. Examples of such variables include changes in soil molsture, summer precipitation, or extreme temperature 
by region, and in the number of days in a row when the temperature exceeds a threshold value important to particular activities or natural processes. There is general agreement among climate modelers that, while precipitation would increase globally in a global warming scenario, regional patterns of precipitation would probably change, leaving some areas considerably wetter or drier. Translating these precipitation changes into changes in soil moisture is yet another question, since soil moisture is a function of soil and vegetation characteristics as well as precipitation, temperature, and humidity. Differences in soil moisture and temperature could also affect the soil's capacity to absorb greenhouse gases. Some models suggest a marked soil moisture decrease in midlatitude continental regions during summer. Coordination between climate modelers and experts in impact assessment is required to assure that the efforts of the former are directed towards the development of refined projections of those climate variables that are most critical to the refinement of current impact estimates and the development of new ones.

\section{Policy Alternatives}

The next two sections of this report consider the two basic lypes of policies available to deal with global change: adaplation and mitigation.

Adaptation policies, which seek to lower the costs of global warming, come in two forms: planned and unplanned. Planned adaptation involves actions taken in advance of anticipated warming; examples include development of heat-resistant plant strains and decisions not to undertake new construction on land that may be inundated by sea-level rise. Unplanned adaptation involves reactions to actual warming, such as the use of more air conditioning. For the most part, effective planned adaptation policies can be designed and implemented at the local or national levels, while unplanned adaptation mainly reflects decisions of individual firms and houscholds. If global warming occurs over time, adaptation would alse be a continuing process.
Mitigation policies are aimed at reducing net emissions of greenhouse gases: This can be done cither by reducing gross emissions (by reducing the use of CFCs (or the burning of fossil fuels, for instance) or by increasing the removal of greenhouse gases from the atmosphere by natural processes (by reforestation, for irstance).

Because some greenhouse gases have long atmospheric lifetimes, and because any changes in climate are predicted to lag changes in net emissions by many decades, mitigation policies must generally be implemented well before adaptation policies. Using a 5 -percent real discount rate, $\$ 100$ billion spent on adaptation in 2050 is equivalent in terms of cost to $\$ 4.2$ billion spent on mitigation today. (If an investment yields a 9-percent rate of interest in dollar terms, but prices rise at 4 percent per year, the real purchasing power of invested funds grows by 5 percent annually.) A 5-percent real discount rate is used throughout this report, but the economic literature contains arguments for both higher and lower rates.) Because the time scales here are longer than in most issucs, the important economic implications of differences in timing between adaptation and mitigation can only be revealed by discounting.

The estimates of impacts and adaptation costs discussed in this report reflect a wide range of analytic methods, assumptions regarding the magnitude and timing of possible climate change, and time periods over which impacts are considered. These disparities rule out meaningful summation of estimated impacts across studies. In general, impacts and adaptation costs are estimated for either one or a small set of assumed climate-change scenarios, with the latter characterized in terms of factors such as the change in mean temperature or mean sea level. Costs and other impacts are almost always estimated relative to an implicit or explicit baseline involving no climate change. Such estimates could in principle be used to measure the benefits of entirely forestalling climate change. However, they necessarily overstate the benefits of mitigation policies that merely slow climate change. the available literature on mitigation costs does not 
even consider policies stringent enough to rule out climate change entirely.

Effective policy design must reflect the fact that there are great uncertainties about future emissions, implied climate changes and their effects, and the costs of reducing net emissions. It is of course important to support scientific and economic research to close the many gaps in our knowledge. But it is also important to recognize that policies adopted today may vary significantly in their attractiveness as uncertainty is reduced in the future. The benefts and costs of proposed policy actions should be evaluated under a broad range of outcomes that reflect the significant uncertainties that pervade the global climate issue. Flexible policies that can easily be reversed or expanded, and policies that can be justified for reasons other than climate change should be highly valued. This approach has been promoted by the United States in the international community since Secretary Baker's February 1989 address to the Response Strategies Working Group (RSWG) of the IPCC. 


\section{ADAPTATION: LIVING WITH GLOBAL WARMING}

This section considers the economic costs of global warming as described in Section I.B, above. We begin with an overview of the general effects of climate change on the economy. The rest of this section then considers the specific effects and related planned adaptation policies on which most attention has been focused, concentrating on the period between now and the middle of the next century.

\section{A. Climate and the Economy}

Climate change can affect economic activity both directly, by altering production possibilities, and indirectly, as adaptation to change and its direct effects alters demands for and supplies of particular goods and services. For example, warming would directly affect operators of ski areas and indirectly affect manufacturer's of ski equipment.

The direct economic effects of climate change would be concentrated primarily in agriculture, forestry, and fisheries, which currently account for about 2 percent of U.S. grosis domestic product (GDP) and about 5 percent of world GDP. These effects are not all negative since, for example, the construction industry would benefit directly from reduced seasonality. Hydropower production would be affected by changes in precipitation and runoff. The subsections that follow focus on the most-discussed direct effects of global warming. Because of gaps in both science and economics, we have comprehensive impact cost estimates only for agriculture and comprehensive adaptation cost estimates only for sea-level rise.

The indirect effects of climate change will create winners and losers throughout the United States and global economies. If energy use is not curbed to reduce greenhouse emissions, for instance, electric utilities and their suppliers could face significantly higher demands (The Environmental Protection Agency (EPA) estimates that a summer temperature increase of $6.7^{\circ} \mathrm{F}$ would require an increase in clectric generating capacity of between 25 and 50 percent of current capacity.) Demand for air conditioners and heat exchangers would rise, benefiting producers of these products. Producers and distributors of space heating equipment, heating fuels, and winter clothing would likely face decreased demand. Using existing econometric models, it is not generally possible to translate qualitative assessments of this sort into quartitative estimates.

The costs of adaptation would depend critically on how rapidly warming occurs. Useful lives of plant and equipment tend to be substantially less than 50 years, so that even a steady change in climate over the next century would permit considerable change in the location and composition of economic activity without major disruptions. If sudden changes were required, the values of some immobile assets would drop sharply, and disruptions would occur. Sudden population shifts, for instance, would lead to the abandonment of buildings, roads, and infrastructure in some areas alcng with the need for major new investments in other areas.

\section{B. Agriculture}

Climate change could affect U.S. agricultural markets directly through changed domestic yiclds and indirectly through changed world prices and trade flows brought about by changed crop production abroad. While a number of possible planned adaptation policies have been identified, their likely costs and effects have not been fully analyzed. 


\section{Potentlal Yleld Effects}

Unforturiately, as noted in section I.B, even given an assumed level of global warming, available predictions of regional temperature, seasonality change, precipitation, and soil moisture vary greatly, leading to highly un ertain agricultural projections. In addition, agricultural effects would vary over time if climate continued to change with gradual increases in atmospheric race gas concentrations.

Recent studies of the effects of climate changes on crop yields include Smith and Tirpak (1989), Parry, et al. (1988a, 1988b), and Santer (1985). These studies suggest that, in general, middle-latitude yields would fall and northern-latitude yields would rise with a doubling of $\mathrm{CO}_{2}$ levels and consequent warming. Most results point to 10 to 20 percent declines in yields in the Southern United States and slight increases in the Northem United States.

These estimates do not incorporate important factors such as farm management response with existing technology, the development of new crop varietics better suited to new climate and ambient $\mathrm{CO}_{2}$ conditions, and changes in hydrology and in the distribution of agricultural pests and diseases. The literature suggests that these factors are likely to be important in determining the net effect of climate change on agriculture (Hansen 1990; Rosenberg et al. 1989). A recent workshop (National Climate Program Office, 1989) that discussed some of these factors concluded that the net effect of trace gas doubling would be to increase yields in all countries by 15 to 40 percent. On the other hand, some argue that the workshop assumed an optimistic change scenaric $\left(3.8^{\circ} \mathrm{F}\right.$ warming and a 15 -percent increase in precipitation) and did not consider ch:anges in pest activity or possible summer droughts.

\section{Economic Implicatlons}

Because national agricultural markets are linked by international trade, the net effect of climate change on any country will depend on how changes in regional climates affect global agriculture, and how these changes affect agricultural prices and trade flows: Because the United States is a large net agricultural exporter, economic losses associated with domestic declines in crop yields could be partially, fully, or more than fully offset by producer gains from the higher agricultural prices that would occur if world supply tightened. The same mechanism would, of course, operate to offset the economic gains stemming from yield increases that sume believe could follow from increases in atmospheric concentrations of $\mathrm{C}^{\mathrm{O}} \mathrm{O}_{2}$.

Kane et al. (1989) used the primary international agricultural trade model of the U.S. Department of Agriculture's (USDA) Economic Research Service (Roningen, 1986) to estimate the economic effects of changes in agricultural yield induced by climate change. That analysis, which deals only with major grain and oilseed crops and does not consider fruits, vegetables, poultry, or livestock, has been updated by USDA for this report. The range of crop yicld estimates used reflects a synthesis of recent suggestions (Parry, et al. 1988a, 1988b; Santer, 1985; Smith and Tirpak, 1989; United Nations, 1989). These estimates (summarized in Table II.1) are largely illustrative because of the high degree of uncertainty concerning the regional yield effects of climate change; note in particular that, in contrast to the National Climate Program Office exercise discussed above, the impact on U.S. yicld is negative.

This analysis predicts a climate-Induced increase in world com and soybean prices of about 10 percent, since most production of these crops occurs in mid-latilude countries that may be adversely affected by climate changes. The prices o." all other primary agricultural commodities are estimated to decline, though prices of oil and meal would risc.

As Table II.1 shows, these estimated price changes would leid to small increases in net U.S. and global welfare. Global welfare rises beciluse decreased production in some regions is more than offset by increases in others. From the perspective of an individual country, large domestic yield elfects do nol necessarily translate into large wellare effects; welfare 
effects depend on prices determined in world markets and on flows of imports and exports. Thus, even though yields are assumed to fall in the United States, U.S. net welfare is estimated to increase by just under $\$ 200$ million in 2050. (These estimates do not consider adaptation costs, such as the possible need to increase irrigated acreage.)

When these welfare effects are discounted to the present, they are seen to be even less important than Table II.1 might suggest. At a 5-percent annual rate of discount, the present discounted value of the estimated $\$ 1.51$ billion of net climate change benefits in world agriculture in 2050 is just $\$ 81$ million. Assuming linear growth in net benefits to 2050, the present discounted value of all net benefits over the next 60 years is only $\$ 8.1$ billion. To put these numbers in perspective, another application of the model used here found that trade-distorting agricultural policies imposed worldwide costs in 1986 alone of $\$ 31$ billion.
Kane, et al. (1989) provide an informative sensitivity analysis. Only when assumed yield reductions in the United States, Canada, and the European Community (EC) are set at very high levels (greater than 40 percent), do welfare effects become greater than 1 percent of GDP in the countrles studied. Thus, even with minimal planned adaptation, it appears that climate-induced changes in agriculture should not produce major national-level economic effects, positive or negative, by the middle of the next century. However, the possibility of substantial variation in regional impacts cannot be ruled out.

\section{Adaptation}

U.S. agriculture can improve its resillence to climate change through several adaptive strategles. These include increasing irrigation and water-use efliciency, developing and planting heat- and drought-resistant crop varictles, enhancing soil and water retention through use of low tillage and crop rotation practices, maintaining and enhancing the genetic and lechnological diversity of agricultural systems, and

Table 11.1 - Estimated Economlc Welfare Effects In 2050 of Cllmate-Induced Agricultural Yleld Changes

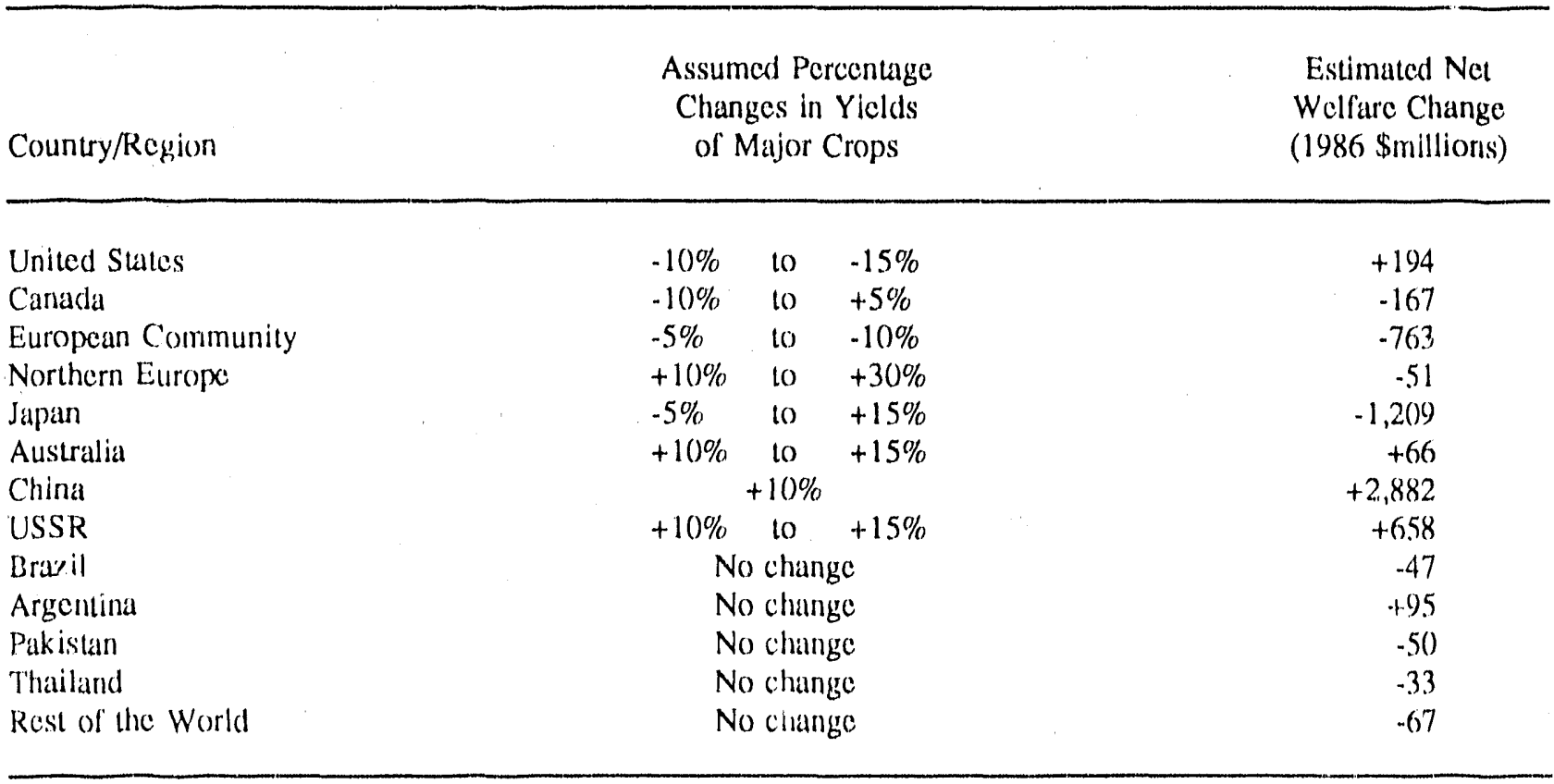


improving pest control techniques in anticipation of possible northward migration of pests. Agrlcultural policles and programs, such as price support and acreage control pollcies, should be reviewed to determine whether there exist modifications that would help ensure timely and efficlent adjustment to possible climate change and that would contribute to trade and other polley goals.

\section{Sea-Level Changes}

The adverse effects of possible sea-level rise on coastal infrastructure, recreation, and coastal ecology could be either large or small. The severity of these effects will be determined by the magnitude and rate of any sea-level rise and whether planned adaptation policles are instituted. Unforturtately, only a few estimates of the costs of sea-level rise or of adaptation policies are avallable.

\section{Possible Impacts}

A foot of sea-level rise can erode a typical beach 100 to 300 fect; a 40 -inch rise could translate into 900 fect of crosion. The U.S. coastline, as that of most other industrial maritime nutions, has been extensively developed, with buildings often within 100 feet of the sea. Even if currently densely developed areas were protected, losses of dryland and coastal wellands could be substantial if rates of rise were rapid.

The loss of land by erosion and flooding due to accelerated sea-level rise would translate into lost economic services. Gibbs (1984) estimated that the present value (using a 3-percent discount rate and in 1980 dollars) of lost economic services to Charleston, South Carolina, due to an 83 centimeter rise in sea level could be $\$ 1.3$ billion. However, planned adaptation could reduce this loss by 65 percent to $\$ 0.4$ billion. The amount of rise considered in this analysis is more than double the high end of the most recent IPCC estimate of likely sea-level rise by 2050 if significant warming occurs.

Other nations could also face losses from any sea-level rise. A 1 -meter rise would inundate 7 percent of the land (occupied by 5 percent of the population) in Bangladesh. Egypt would lose 12 percent of tis habitable land, affecting 14 percent of tis population. The cost to each aation could exceed '2 percent of GDP. No estimates are avallable for the effects of the 25- to 4()-centimeter sea-level rise considered most likely to occur by 2050 if significant warming occurs.

A higher sea level would allow the saltront of rivers to travel further upstream than before and could also allow high salinity water to contaminate groundwater. Huli and Titus (1986) found that with a 1-meter rise in sea level, reservoir capacity would have to be significantly increased to allow Philadelphia to continue withdrawing its drinking water from the Delaware River, New York City, which withdraws water from the Delaware headwaters, would also be affected. Less than $\$ 1$ billion ( $\$ 180$ million to $\$ 908$ million) in present-value capital oullays would be needed to compensate for this possible reduction in water supply following from climate change. (The present values are derived from estimates of $\$ 2.8$ to $\$ 14$ billion in undiscounted 1986 dollars cited by the EPA, assuming a 5-percent real discount rate with all expenditures incurred in 2050.)

Without significant changes in its water management plans, Miami's primary source of drinking water would be rendered unusable by salinity increases if a onc-meter rise in sea level occurred. Even with action, the clty would face reduced supply. Many other communities along the coast could feel similar effects on their drinking water supplies if such a large sea-level rise were to occur.

Storm surges would be likely to increase in height by the amount of sea-level rise, making flood damages more frequent and severe. The size of flood plains would likely increase. As a result, flood insurance costs would probably go up, even with anticipatory policies.

\section{Adaptation}

It would not make economic sense to protect the entire U.S. coastline against any substantial sea-level rise. If the sea level were to rise gradually and predictabiy 
substantial costs could be avolded by discouraging additional development or replacement construction in low-lying arcas (perhaps in part by altering Federal flood insurance policy). Particularly for less developed areas, discouraging development would allow beaches to maintain their natural form, wetlands to migrate landward if rates of sea-level tise are moderate, and flood and storm damage to be minimized.

It might, however, also be necessary to nourish recreational beaches with sand and to use levee systems to protect some densely developed shoreilne areas. Estimates from. Smith and Tirpak (1989) of the costs of these actions through 2100 under alternative sea-level rise assumptions, along with the resulting loss of drylands and wetlands, are shown in Table II.2. (To put the estimated dryland losses in perspective, the land area of Florida, which would be particularly hard-hit by substantial sea-lovel rise, is about 54,000 $\mathrm{mi}^{2}$.) As this table suggests, while densely developed shoreline areas could be protected against likely sea-level rises at moderate (present value) cost, significant losises of drylands and wetlands would occur.

\section{Human Health}

The impacts of global warining on human health are extremely controversial, and the scope for planned adaptation is unclear.

\section{Possible Impacts}

The consensus view of a recent National Research Council Workshop (1987, p. 19) was that "...long-tern. climatic changes in temperate latitudes aro unllkely to have major health implications." Others have noted that even though Atlanta's climate is much warmer than New York's, there is no evidence of a climate-induced difference in health risk.

On the other hand, a recent EPA report (Smith and Tirpak, 1989) finds that warming could lead to increases in summertime morbidity and mortality in the United States and the rest of the world. The report notes that any such effects would be more pronounced in some reglons than in others and that the extent of acclimatization will play a large role in determining the effects of any actual warming on health. The a..parent

Table II.2 - Protecting Densely Developed Shorellne Areas from Sea-Level RIse

\begin{tabular}{|c|c|c|c|c|}
\hline & \multicolumn{4}{|c|}{ Sca-Level Rise by 2100} \\
\hline & Baseline* & $50 \mathrm{~km}$ & $100 \mathrm{~cm}$ & $2,00 \mathrm{~cm}$ \\
\hline \multicolumn{5}{|c|}{$\begin{array}{l}\text { Cumulative Costs to } 2100 \\
\text { (1986 \$billions) }\end{array}$} \\
\hline Present Value** & 0.6 to 0.8 & 3.9 to 5.3 & $9 .()$ to 13.7 & 20.8 to 38.1 \\
\hline Undiscounted Sum & 4.8 to 6.2 & 32 to 43 & 73 to 111 & 169 ๓ 309 \\
\hline $\begin{array}{l}\text { Dryland Lost } \\
\left(\mathrm{mi}^{2}\right)\end{array}$ & $1,5(00)$ to 4,700 & 2,200 to 6,100 & $4,100$ to 9,200$)$ & 6,400 10 13,500 \\
\hline $\begin{array}{l}\text { Current Weiland Lost } \\
\text { (percent) }\end{array}$ & 9 to 25 & 20 to 45 & 29 to 69 & 33 to 80 \\
\hline
\end{tabular}

*Assumes current rale of sea level rise, $12 \mathrm{~cm}$ per century.

**Assumes rate of spending rises 1 percent per year; uses 5 percent real discount rate (continuous time). 
absence of a climate-related difference in health risk between northem and southem cities and the lesser effect of current heat waves on mortality in southern citles suggests that human populations could acclimatize, especially if warming occurred over several decades. The EPA report also notes that any warming would probably reduce the number of weather related deaths in winter months regardless of the degree of acclimatization. The report concludes that it is not clear what the net effect of these two offsetting trends may be, but one of the underlying papers suggests that an overall increase in mortality is most likely.

Several vector-borne diseases, such as yellow fever, dengue fever, and malaria, have the potential to spread northward If the climate warms. For example, the vector of dengue fever breeds year-round in the United States only in southern Florida, but it could move northward by several hundred miles. The National Rescarch Council Workshop (1987, p. 19) concluded that the expansion of ranges of tmpical disease vectors "would mostly affect developing countries." Public health facilitics in these nations could not readily handle a dramatic increase in infectious disease with their current resources. Their future ability to cope would depend largely on the rate of improvement in living standards.

\section{Adaptation}

A national watch/warning system could be developed (much like the systems that now warn of hurricanes and severe snowstorms) to advise people when stressful weather conditions are imminent. Immunization programs could be conducted in anticipation of the spread of certain vector-borne diseases into new areas. An improved health-screening program could be developed for immigrants. Tinally, improved surveillance systems could provide better data on the incidence and spread of infectious discases.

\section{E. Other Potentlal Effects}

This subsection considers the implications of possible global warming for forestry, fisheries, water resources, and blodiversity. While a variety of possible adverse impacts have been identifted in each of these areas, little quantitative analysis has been attempted to date.

\section{Forestry}

Climate changes could have a significant impact on the forestry industry. Unfortunately, no attempts have yet been made to quantify the economic impact of such changes on producers or consumers. As in agriculture, both yield and price effects are relevant.

a. Possibie Impacts. If significant warming occurs, climate-induced changes in U.S. forests could be apparent in 30 to 80 years. Forest ranges could shrink considerably. The southern boundary of forests in the eastem United States could move several hundred to one thousand kilometers north under plausible global change scenarios. The potential northern range could shift by as much as 600 to 700 kilometers over the next century under these scenarios, but slow rates of natural forest migration could limit the actual movement to as little as 100 kilometers. Northward migration may also be limited by less fertile soils and decreased sunlight availability in the North. These projections do not account for the favorable effects of $\mathrm{CO}_{2}$ on water-use efficiency and rates of photosynthesis, reductions in freeze damage, or human intervention in the forest migration process.

Changes in forest distribution and composition could have major impacts on timber production, runoff from forests, and recreational opportunities. Dicback along the solthern limits of U.S. forests could result in productivity declines in present dominant species of 46 to 100 percent under some plausible scenarios. This estimate does not account for human intervention, such as specics transplantation. The response of forests to climate change could also modify runoff patterns and increase the potential for soil crosion.

Forests in other regions of the world would also be affected by significant warming. A recent analysis for the IPCC (Government of Finland, 1989) suggests that boreal forests will become more productive if significant warming occurs. Others believe that these 
same forests would be especially hard hil, since most climate models suggest that any warming that occurs would be greatest in high latitudes. While temperature increases may be smaller in the tropics, tropical forests could be significantly affected by changes in rainfall and land-use pressures that may impede forest migration to more suitable locations.

\section{b. Adaptation. Today's forest management decisions} could have long-term impacts on the composition and location of forests. Planned adaptation measures that could be considered include maintaining forest diversity and extensiveness to enhance the ability of forests to respond to a range of climatic conditions; developing and testing fast-growing and heat- and drought-resistant species; preparing for dieback along southem boundaries with plans for rapid harvesting and removal of dead trees and replacement with better adapted species or nonforest systems; improving capabilities for monitoring changes in forest growth and composition; and modifying pest and fire control strategies to rellect likely changes in the frequency and nature of these disturbances.

\section{Flsherles}

The effects of global warming on fisheries depend primarily on changes in regional climates and ocean circulaticn and on the pace at which they occul: The qualitative effects of warming on fisheries are thus highly uncertain, and no quantitative economic analysis has, to our knowledge, been attempted.

a. Possible Impacts. The impacts of any significant change in temperature on fish populations would vary across specles. Some would experience increased habitat and associated expansion of range. Adaptation would be casier for fish in large bodies of water, including the oceans, than for those constrained in small water bodics. Total productivity of fishing grounds in the Great Lakes and oceans could increase. Under some scenarios, phytoplankton and fishery productivity could increase in the Great Lakes by 1.6 to 2.7 fold, but there is the potential for a decrease in diversity due to intensified species interactions. Climate change effects on the ocean are particularly uncertain due to the complexities surrounding ocean circulation, which until recently has not been explicitly considered in climate models, heat uptake by the ocean, and future patterns of nutrient upwelling. One study found that many Gulf Coast fish and shellfish would be unable to tolerate much higher temperatures.

If there is rapid sea-level rise and resulting saltwater intrusion and wetlands loss, changes in the distribution and size of many estuarine species would be possible. Any losses of coastal wetlands would adversely alfect fish. Species that are less salt-lolerant would tend to migrate upstream towards suitable habitat, ceding present habitats to species that are more salt-tolerant. In lakes, streams, and estuaries, declines in water quality due to reduced dissolved oxygen levels at the higher temperatures in some scenarios could adversely affect many recreational species.

In the tropics, species dependent upon coral reefs could experience significant adverse effects. Coral reef ecosystems could be vulnerable both to increased thermal stress and to sea-level rise, if it were rapid enough to inundate and kill the coral species.

b. Adaptation. Both the need and the opportunity for planned adapiation appears to be limited. Commercial fishing occurs primarily in the ocean, where effects of possible climate changes are especially uncertain. Changes in species location and composition could require some adjustments, but commercial fisheries now make similar adjustrnents in response to overfishing and the natural movement of species. Travel time to specific commercial fisheries may rise or fall, and changes in available species may raise or lower equipment cost. If equipment adjustınents were made gradually, as durable assets were replaced, their costs would be relatively small.

Management of water flow to lakes and streams could affect fish populations in those water bodies. Restocking, which already plays an important role in recreational fisheries, and new species introduction could aid in adaptation to climate change. Reducing 
water pollution could offset adverse warming impacts on some species.

\section{Water Resources}

Even if an assumed rise in regional temperature is taken as given, it is difficult to predict the impacts of climate change on water basins with much confidence because of uncertainties about regional precipitation. The quantitative estimates that follow assume a U.S. temperature increase of $5.4^{\circ} \mathrm{F}$ to $9^{\circ} \mathrm{F}$ and an annual precipitation increase of 1 to 3 inches

a. Possible Impacts. Such higher temperatures would likely reduce snowpacks by shortening the snow season and causing more precipitation to fall as rain. This could have a significant effect on the operation of such water systems as the Central Valley Project and the State Water System in California. With no change in infrastructure, earlier snowmelt would raise flood probabilities in the winter. Management response to this would reduce annual deliveries by 7 to 16 percent. Similar problems could be expected in other Western water management systems.

Because of uncertainties about rainfall, it is hard to estimate the direction of change in water supply in many regions. This is especially true for rivers that are not fed by snowpacks, such as many rivers in the Southeast. Higher temperatures could lower many lake and reservoir levels through the effects of increased evaporation that was not offset by increased rainfall. For example, the levels of the Great Lakes could fall by an average of 0.5 to 2.5 meters, which could, among other things, reduce dilution capacity. On the other side of the coin, the Great Lakes would benefit from a longer shipping season and a reduction in water pollution due to reduced use of salt and other chemicals to cope with ice and snow.

If adverse developments occur, future costs would be incurred. For example, the future costs of building additional reservoirs for the California systems could be over $\$ 500$ million (undiscounted) and the costs of dredging harbors and making other adjustments could cost $\$ 270$ to $\$ 540$ million (undiscounted) along the
Illinois shoreline alone. (Note that a $\$ 500$ million outlay rec'dired in 2020 could be financed from the proceeds of an investment of only $\$ 116$ million today, assuming a 5-percent real raie of return on invested funds.)

The implications for water quality are mixed. Dissolved oxygen levels could be lower because oxygen is less soluble in higher temperature water and because higher temperatures may increase primary aquatic productivity, which increases the demand for oxygen. Summer stratification could be lengthened in some lakes, which, combined with higher demand for oxygen, would reduce dissolved oxygen levels and harm aquatic life. These factors could lead to lower water quality in some basins. However, reduced use of chemicals to cope with ice and snow would contribute to improved water quality in some northem areas.

b. Adaptation. A number of measures could be taken to increase the resiliency of water resources to climate change. Water conservation could be promoted by reducing or eliminating subsidics for water use or allowing trading of market rights. Water resource managers could be encouraged to explore ways to transfer water between neighboring systems during droughts and to consider plausible climate change in sizing new long-lived facilities. New drought-resistant species could be developed to help cope with any water shortages in agricultural areas.

\section{Blodiversity}

Other effects of possible global warming include $a$ possible decline in biodiversity stemming from the loss or change of habitats that result in the decline or loss of some animal and plant species. Winile the relevant mechanisms can be described, their effects under different climate change scenarios have not been estimated.

a. Possible Impacts. Changes in climate would harm some species but benefit others. The ability of a natural community to adapt to changing climatic conditions would depend on the rate and character of climate change, the size of species ranges, the dispersal rates of 
individual species, and whether or not barriers to migration are present. A species' ability to adapt to changing climatic conditions would be heavily irifluenced by dependencies upon or competition with other species within the ecosystem. For this reason, the impacts of climate change on natural communities are difficult to predict.

In general, communities near the edge of a species range and arctic communities would be at particular risk from significant climate change, as would species that migrate slowly, that are already threatened or endangered, that are specialized to small and isolated environments (such as montane and alpine communities) or that have narrow habitat requirements. In some ases, man-made barriers may limit migration: examples include mammals isolated in refuges and prairie species blocked by expansive agriculture.

b. Adaptation. Existing programs that focus on the protection of endangered species and preservation of genetic diversity could be adjusted if the number of species at risk grows. Expansion of reserves and creation of migratory pathways between areas of suitable habitat could enhance our ability to preserve species. It may be useful to develop forest management practices that allow product extraction while minimizing any reductions in an area's future use as wildlife habitat. Areas that may become suitable future habitat for threatened and endangered species, such as lowland areas adjacent to current wetlands, could be identified and considered for protection. 


\section{III.' MITIGATION: LIMITING GREENHOUSE GAS EMISSIONS}

As indicated in Section $\mathrm{I}$, the analysis of mitigation strategies must consider emissions of multiple gases arising from many different economic activities in many nations. The first subsection provides some basic assumptions and principles about altemative policies for reducing greenhouse emissions. Estimates of the costs of reducing emissions of each of the main greenhouse gases are then discussed. The costs of reducing carbon dioxide and chlorofluorocarbon emissions have received the most attention. Estimates of carbon dioxide abatement costs remain preliminary and controversial. Relatively little is known about the costs of reducing emissions of other greenhouse gases. Major studies of mitigation policies are under way within the Federal Government (in DOE, EPA, DOI, and OTA; a CBO study will be published in August 1990), within foreign governments, and in the private and nonprofil sectors (work is under way at EPRI, Harvard, MIT, and Stanford). A revision of this section a year or two from now could rely on a much deeper research base and might have different policy implications.

\section{A. Background}

Two points are basic to any discussion of mitigation policies. First, global action is essential if meaningful results are to be obtained without bringing economic growth to a halt in some regions. Second, as in other regulatory arenas, mitigation policies should minimize costs by relying on incentives to the maximum possible extent and by providing flexibility.

\section{Global Action}

Table III.1 summarizes some key data from Section I. Anthropogenic emissions of methane and nitrous oxide are mainly agricultural in origin and are mainly produced by the developing nations; it is clear that global action, concentrating on agriculture, would be necessary if a digcision were taken to control $\mathrm{CH}_{4}$ and $\mathrm{N}_{2} \mathrm{O}$ emissions. While current $\mathrm{CFC}$ emissions are mainly produced by the Organization for Economy Cooperation and Development (OECD) member states (which have already pledged significant reductions and are likcly to commit to a near total phaseout), CFC emissions of other nations are predicted to rise rapidly in the future if no additional controls are put in place.

Table III.1 - Anthropogenlc Greenhouse Gas Emissions

\begin{tabular}{|c|c|c|c|c|}
\hline \multirow[b]{2}{*}{ Gas } & \multirow{2}{*}{$\begin{array}{l}\text { Percentage Share } \\
\text { of Radiative Forcing } \\
\text { in the } 1980 \mathrm{~s}\end{array}$} & \multicolumn{3}{|c|}{ Percentage Share of 1985 Emissions } \\
\hline & & $\begin{array}{l}\text { OECD } \\
\text { Nations }\end{array}$ & $\begin{array}{l}\text { USSR/East } \\
\text { Europe }\end{array}$ & $\begin{array}{l}\text { CP Asia/ } \\
\text { Developing }\end{array}$ \\
\hline Carbon Dioxide $\left(\mathrm{CO}_{2}\right)$ & 49 & 43 & 22 & 35 \\
\hline Methane $\left(\mathrm{CH}_{4}\right)$ & 19 & 25 & 13 & 66 \\
\hline Chlorofluorocarbons (CFCs) & 14 & 65 & 16 & 18 \\
\hline Nitrous Oxide $\left(\mathrm{N}_{2} \mathrm{O}\right)$ & 5 & 27 & 14 & 59 \\
\hline
\end{tabular}


Finally, while the OECD nations are now the single largest source of anthropogenic carbon dioxide emissions; cmissions of other nations, which already account for more than half of total emissions, are expected to increase rapidly absent serious mitigation efforts. The OECD share of $\mathrm{CO}_{2}$ emissions is projected to fall below 25 percent by 2050. Taking account of expected future emissions patterns, the need for global action is evident for these gases as well.

Table III.2 considers the effect on global $\mathrm{CO}_{2}$ cmissions in 2025 of the unilateral adoption by the U.S. or by all OECD nations of four frequently discussed emission limitation targets: reduction of emissions growth by 50 percent, stabilizing emissions at 1985 levels by the year 2000, reducing emissions 20 percent below 1985 levels by 2005, and reducing emissions 50 percent below 1985 levels by 2025 . Though the underlying global and regional emission scenarios on which the calculation is based are necessarily uncertain, the basic message of this table is fairly robust: even drastic reductions by all $O E C D$ nations cannot prevent substantial increases in world $\mathrm{CO}_{2}$ emissions by 2025 . Unilateral actions by the U.S. have even smaller effects.
Table III.3 considers the implications of mecting the emission policy targets of Table III.2 on a global basis if nations outside the OECD lake actions that are significant but less than proportional to the targets. The table shows that without full participation by other nations, the OECD member states would have to make dramatic or impossible cuts to meet widely discussed global $\mathrm{CO}_{2}$ emissions goals.

\section{Differentlal impacts}

While global action may be essential for effective mitigation, differences in costs and benefits among nations may make it difficult to obtain global agreement on specific policies. Table III.4 shows that $\mathrm{CO}_{2}$ emissions per capita and per dollar of GNP vary substantially. Among those countries for which GNP estimates are available, higher-income nations tend to have higher emissions per capita but lower emissions per dollar of GNP. The USSR and Eastern European countries have particularly high emissions. These variations make it easy to imagine an international replay of the "clean states $v$, dirty states" debates that have marked Congressional consideration of acid rain proposals. The stakes for oil-exporting nations may be particularly high (Whalley and Wigle, 1989).

\section{Table III.2 - Global Effects of Unllateral Carbon Dloxide Emissions Reductlons by the United States or the OECD}

(Global Emissions In 1985=100)

Global Carbon Dioxide Emissions in 2025 if Policy Adopted by

Emissions Policy U.S. Only All OECD

Base Case (No intervention)

Reduce Growth by 50\%

Stabilize by 20000

Reduce $20 \%$ by 2005

Reduce $50 \%$ by 2025
203

203

194

188
207

182

169

Note: Based on RCW scenario in Lashof and Tirpak (1989), using 1985 emissions as the baseline. 
The United States has a relatively high per capita $\mathrm{CO}_{2}$ emissions rate for two reasons. First, U.S, energy intensity (as measured by British thermal units consumed per constant dollar of GNP) is higher than that of most of our major competitors. It is double that of Japan and 75 percent above than of Western Europe. Second, coal provides about 27 percent of total U.S, energy requirements. Among major industrial countries, this share is exceeded only by the U.K. ( 32 percent) and West Germany (29 percent). The United States also relies less heavily on nuclear power than do many other industrialized countries.

Because the United States relies heavily on coal (the fossil fuel with the highest amount of carbon per unit of energy) for electricity generation, U.S. electricity rates would be likely to rise more than those in other industrialized countries if concerted action were laken-for example, by imposing the same charge on the carbon content of fossil fuel-to curb $\mathrm{CO}_{2}$ emissions. Unless energy-intensive U.S. industries were able to greatly increase their energy efficiency, they could be disadvantaged relative to major foreign competitors who would be less affected by electricity rate increases.

In addition, because the United States has an abundance of coal reserves, and very little undeveloped economical hydroelectric potential, limits on coal use would likely result in larger imports of oil and gas, which will have implications for our balance of trade and energy security. All of this presents a marked contrast to the 1973 and 1979 oll shocks, where our greater self-sufficiency in energy provided an advantage relative to most other industrialized nations. On the other hand, our more energy-efficient competitors may find it relatively harder to reduce emissions in the future, since they have already undertaken cheap efficiency measures that we have not.

Since adaptation costs are likely to vary substantially among nations, so may interest in investing in mitigation. Existing models suggest greater warming in high northern latitudes, and less warming in latitudes where most developing nations are located. There is likely to be considerable regional variation in

Table III.3 - OECD Carbon Dloxide EmIssions Reductions Required To Achleve Global Emisslun Goals When Other Natlons Take Lesser Actions (Base case global emlsslons $=100$ in 1985, 207 in 2025)

\begin{tabular}{|c|c|c|c|}
\hline \multirow[b]{2}{*}{ Global Goal } & \multicolumn{2}{|c|}{ Action Assumed Taken by } & \multirow{2}{*}{$\begin{array}{c}\text { Required } \\
\text { OECD Reduction }\end{array}$} \\
\hline & USSR/E. Europe & Developing Nations & \\
\hline \multirow[t]{2}{*}{ Cut Growth 50\% } & Growth cut $25 \%$ & None & $98 \%$ by 2025 \\
\hline & Growth clit 25\% & Growth cut by $25 \%$ & $33 \%$ by 2025 \\
\hline \multirow[t]{2}{*}{ Stabilize by 2000} & Growth cut $50 \%$ & Growth cut by $25 \%$ & $41 \%$ by 2000 \\
\hline & Growth cut $50 \%$ & Growth cut by $50 \%$ & $29 \%$ by 2000 \\
\hline \multirow{2}{*}{ Cut $20 \%$ by 2005} & Stabilize & None & Excecds $100 \%$ \\
\hline & Stabilize & Stabilize & $46 \%$ by $2(x) 5$ \\
\hline \multirow[t]{2}{*}{ Cut $50 \%$ by 2025} & Cut $20 \%$ by 2025 & None & Exceeds $100 \%$ \\
\hline & Cut $20 \%$ by 2025 & Cut $20 \%$ by 2025 & $89 \%$ by 2025 \\
\hline
\end{tabular}

Notes: Based on RCW scenario in Lashof and Tirpak (1989), using 1985 emissions as the baseline. Developing Nations include Centrally Planned Asia. 
Table III.4 - Carbon Dloxide EmIsslons Per Caplta and Per Dollar of GNP, 1986

\begin{tabular}{lcc}
\hline Country & $\begin{array}{c}\text { Per Capita } \\
\text { (metric tons of carbon } \\
\text { per capita) }\end{array}$ & $\begin{array}{c}\text { Per Dollar of GNP } \\
\text { (kilograms of } \\
\text { carbon per dollar) }\end{array}$ \\
\hline United States & 5.005 & 0.28 \\
Canada & 4.094 & 0.29 \\
Japan & 2.109 & 0.16 \\
West Germany & 3.066 & 0.25 \\
Australia & 3.853 & 0.32 \\
France & 1.794 & 0.17 \\
United Kingdom & 2.938 & 0.33 \\
Italy & 1.655 & 0.19 \\
Spain & 1.284 & 0.26 \\
Poland & 3.321 & 1.60 \\
Mexico & 0.909 & 0.49 \\
South Africa & 2.785 & 1.51 \\
Brazil & 0.379 & 0.21 \\
China & 0.527 & 1.76 \\
India & 0.187 & 0.64 \\
& & \\
East Germany & 5.499 & $\mathrm{n} . \mathrm{a}$. \\
Czechoslovakia & 4.212 & $\mathrm{n} . \mathrm{a}$. \\
USSR & 3.593 & $\mathrm{n} . \mathrm{a}$. \\
Romania & 2.408 & $\mathrm{n} . \mathrm{a}$. \\
\hline
\end{tabular}

Notes: From Department of Energy and World Bank Development Report, 1988. Top set of countries listed from highest to lowest GNP per capita. Includes emissions from fossil fuel combustion and cement production only.

n.a.= means GNP not available in the sources employed.

agricultural effects. Nations differ substantially 'n their vulnerability to sea-level rise. A higher share of GNP originates in climate-sensitive activities in developing nations, but these nations generally lack resources for adaptation. In short, while global action is essential to limit greenhouse emissions significantly, differences among nations may make it difficult to find universally acceptable emissions targets or ways of sharing the costs involved.

\section{Incentlves and Market Faliures}

Consistent with its approach to domestic regulatory issues, this Administration feels that an approach to limiting net anthropogenic greenhouse emissions that encompasses all important greenhouse gases and gas sinks as well as gas sources' is more promising than one that considers each source of greenhouse gases individually, An international limitation agreenent based on the comprehensive approach, for example, would allow each nation to devise a strategy that reflects its own situation regarding opportunities for emissions reduction and sink enhancement. The Administration also feels that any set of nations should be free at any time to develop a joint strategy to meet their pooled ceilings, as long as net global emissions are not thereby increased. An approach incorporating these principles was outlined in a U.S. concept paper introduced at the IPCC. 
Even if a comprehensive approach with provision for pooling were accepted, opinions are divided on how indlvidual nallons-in particular the United Statesshould set domestic policy to meet net emission limitation targets. Most economists argue that primary reliance should be placed on incentive-based approaches-including charges, user fees, and tradable. emissions rights. This view follows from the presumption that households and firms generally respond rationally to incentives, so that regulatory goals are met at least cost by providing proper incentives and maximal flexibility to respond at all points along the production-consumption chain.

A second school of thought tends nonetheless to favor the use of efficiency standards and other commandand-control techniques. Adherents of this school point to apparent widespread deviations from best practice in energy use and to reports of large payoffs from utility conservation programs as indications of market failure. They contend that government regulation can reduce $\mathrm{CO}_{2}$ emissions, in particular, at low or even negative cost by helping or forcing individuals to take actions that are, in fact, in their own self-interest.

Market failures do not, of course, provide an automatic justification for regulation. Market failures, where they exist, can be addressed directly. For example, since utility profits under traditional State rate regulation are often linked directly to the level of electricity sales, a utility faced with capacity constraints would usually prefer to increase supply rather than reduce demand. Regulatory changes at the State level could be made to place the alternatives of demand reduction and supply augmentation on a more even footing. Public information programs, promotion of efficient appliances by utillties, and changes in mortgage qualification rules to reflect appliance operating costs are other steps that could be used to deal with market failures direcily.

Efficiency standards and other command-and-control regulations have several significant disadvantages relative to incentive-based systems or approaches that aduress perceived market failures directly. First, the burden of meeting standards cannot be reallocated across industries or across the different greenhouse gases in private cost-saving transactions. Second, in the absence of price increases for fossil fuels, standards can increase the demand for energy-using services. Finally, standards reduce the range of products available to meet diverse consumer needs.

The costs of efficiency standards are often hidden rather than explicit. For example, a higher average fuel economy standard might be met by forcing consumers to buy only the more fuel-efficient and generally cheaper vehicles in the existing product line, actually reducing their purchase and gasoline costs. However, out-of-pocket costs do not reflect costs imposed on consumers by denying them the option to purchase other valued attributes such as safety, performance, and spaciousness. Higher fuel efficlency without higher fuel prices also lowers the per-mile cost of driving, encouraging additional trips, fuel consumption, and emissions. Since fuel economy labels already provide good information to auto purchasers, and there are lew apparent institutionil rigidities in this market, the economic rationale for stringent vehicle efficiency standards is doubtful at best.

More generally, assertions that efficiency improvements are cost saving or nearly costless raise the classic question of why these improvements are not automatically taking place. Such assertions must be examined to see if the claimed efficiency gains involve tradeoffs with other product attributes that were excluded from the analysis.

Efficiency standards based on national average values may actually serve to restrict the choices of only those consumers who face low energy prices or have low usage rates (and thus energy consumption) for the product. Those with high usage rates or those who face high energy prices would purchase high-efficiency products even in the absence of mandatory standards. Taking this self-selection into consideration, an efficiency standard that appears to save money on the national level may actually impose costs on many consumicrs. 
Economic models populated by perfectly rational firms and houscholds participating in perfect markets that are always in equillbrium clearly do not provide a fully reallistic characlerization of the U.S. economy, But the alternative extreme assumption, of widespread private waste casily corrected by regulation but untouchable by market incentives or direct correction of market fallures, seems at least as far off the mark. The question of where truth lles between these extromes is ultimately empirical, and it cannot be answered here.

It is important, however, to point out that essentially all analysts agree that some reductions in greenhouse gas emissions can be obtained at low cost. Disagrecments focus on how fast the marginal cost of abatement rises and on how the initial, low-cost reductions can best be obtained.

\section{B. Carbon Dioxide}

Carbon dioxide accounted for about 49 percent of the increase in radiative forcing in the 1980's and is expected to account for a larger share in the future. The Administration's acid rain proposals, by providing incentives to conserve electricity, will reduce $\mathrm{CO}_{2}$ emissions from electric utilities by around 2 percentand will thus reduce total U.S. fossil-fuel $\mathrm{CO}_{2}$ emissions by around 0.7 percent. The higher corporate average fuel economy (CAFE) standards adopted lasi spring will be likely to slow the increase in $\mathrm{CO}_{2}$ emissions from automobiles.

Below, we begin by considering the estimated costs of $\mathrm{CO}_{2}$ cmissions reductions produced by economy-wide models. These models generally assume that markets work well, so that incentive-based approaches minimize the costs of emission reduction. We then consider analyses of the ability of regulatory initiatives to reduce emissions. These analyses tend to be sector specific and focus on markct or policy fallures. The final two subsections focus on the potential of new technologies and of forestation policies.

\section{Economy-Wide Analyses of Em/ssions Limitation Costs}

Several recent studies, and work now in progress on which we have been briefed, attempt to estimate the costs of efficient reductions in $\mathrm{CO}_{2}$ cmisstons levels, using three distinct economy-wide modeling frameworks. Energy/economic balance analysis focuses on the long-term relationship between energy use and output, without explicit consideration of substitution possibilities within the energy sector or the economy as a whole. Energy policy models also focus on the long run but explicitly incorporate substitution possibilities among fuels and the responsiveness of overall energy demand to changes in energy prices and income levels. These models often incorporate a crude feedback from encrgy to GNP, but the main causality runs from the economy to the energy sector rather than vice 'versal. Energy-economic models, which exist in both short-and long-term variants, attempt to incorporate a fuller two-way link between the energy sector and the economy at large, but they tend to include less detailed treatment of energy production and consumption. While all of these approaches have clear weaknesses that point out the need for further rescarch and the development of more comprehensive models, each provides some useful information, and all are considered here.

Costs are estimated in models of the latter two varletics by comparing economies with and without cmissions reductions. Assumptions about emissions growth in the no-policy baseline case vary widely and contribute to the diversity of results obtained. Assumed annual growth rates in $\mathrm{CO}_{2}$ emissions through 2050 vary from 0.61 percent (Edmonds, et al., 1986) to 2.27 percent (Edmonds and Reilly, 1983). Even small differences in bascline annual emissions growth rates (BAEGRs) can have a major effect on levels of emissions over the long lime intervals considered in global climate analysis. For example, an increase of average annual emissions growth from 0.6 pereent to 1.6 percent translates into a 43 percent increase in annual cmissions levels by 2050). Higher BAEGRs translate 
Into higher, somelimes much higher, costs of meeting particular larget emtssions lovels.

For high BAEGRs, even quite draconlan policios do not significantly shlft the date at which atmospheric $\mathrm{CO}_{2}$ concentrations double from preindustrial values. For lower BAEGRs, policles to stabllize emissions appear to be more feasible. The different scenartos evaluated in the models considered below are bost thought of as lllustrative scenarios-possible sets of internally conststent future developments-rather than as definltive foreciasts.

While the studles discussed below differ in many respects, and their shortcomings point up the need for further economic research, they all suggest that the costs of stabilization or reduction of $\mathrm{CO}_{2}$ emissions. will be high-at least I percent of GNP per year for commonly discussised goals such as the indefinite stabilization of emissions between 80 and 100 percent of present leve's. One percent of current world GNP is about $\$ 150$ billion; if world GNP grows at an average annual rate of 3 percent, the total cost to 2050 (discounted at 5 percient) of 1 percent of GNP per year. would come to about $\$ 5.2$ trillion. If economic growth is significantly slowed, costs could be much higher.

a. Energy/Economic Balance Analysis, Kaya (1989) and Kaya, of al. (1989) work from the following identity:

Growth rate of $\mathrm{CO}_{2}$ emissions $=$

growth rate of $\mathrm{CO}_{2}$ emissions per unit of energy use

+ growth rale of energy use per unit of output

+ growth rale of sutput

A -1.0-percent growth rate of energy use per unit of output is assumed, along with a growth rate of $\mathrm{CO}_{2} \mathrm{per}$ unit of energy use of between -0.4 and -1.0 percent. The former estirnate may be viewed as somewhat pessimistic, especially if a substantial rise in energy prices occurs. The latter estimate is rather optimistic given the likelihood of increasing reliance on coal and coal-based synthetic fucls that are highly carbon intensive.
Under these assumptions, a $\mathrm{CO}_{2}$ cmisslons growith rate of -1.0 percent, which is necossary to implement a 20)-percent cut in emissions by 2005, is associated with world output growth of 0.4 to 1.0 percent per year. Over the last several decades, oulput has grown at 4 to 5 percent annually, and population has grown at a 2-percent rate. Thus, these calculations suggest a drop in output growth of 3 to 4 percentage points per year, leading to an almost certain decline in per capita income. The long-run effect on the world economy of a drop in outpul growth of even a tenth of the stre suggested by Kaya's work would be staggering.

Fortunately, our experience following the 1973 and 1979 oil shocks indicates that the relationship between economle growth and energy use may be less rigld than Kaya's framework suggests. Between 1973 and 1985 , the price of energy rose by 47 percent relative to nonenergy products at the consumer level and by 80 pereent at the industrial level. Partly as a consequence, the ratio of energy use to real GNP fell by 2.4 percent annually in the United States and 1.9 percent annually in the OECD countries. $\mathrm{CO}_{2}$ per unit of energy also fell during this period, as usage of natural gas and nuclear power increased rapidly, and U.S. and OECD $\mathrm{CO}_{2}$ emissions were essisentially constant between 1973 and 1985.

This was not a period of economic boom, however; growth rates of U.S. output and productivity over the 1973-85 period, 2.3 percent and 1.0 percent respectively, were far below the corresponding rates of 3.7. percent and 2.9 percent for the 1948-73 pre-shock period. While most of the slowdown in growth can be attributed to other factors, higher energy prices played an important role. The rise in energy prices led to a substitution of other inputs for energy and a diversion of investment that might otherwise have been used to increasc labor productivity.

Moreover, part of the decline in the energy/GNP ratio during 1973-85 reflects the increased relative importance of the service sector. One cannot count on comparable increases in the future, especially as the United States moves from being a large net importer of 
manufactured products to a large net exporter in order to balance its current acoount and repay intemational borrowing.

While the use of nutural gas could continue to expand in the near term, the absence of nuclear projects in the pipeline and current strong public resistance to this form of power in the United States suggest if will be harder to substltute nuclear for fossil energy in the future than in the 1973-85 period. On the other hand, many have argued that macroeconomic policles and energy regulation contributed signiflcantly to the poor economic performance of that pertod and that some of these mistakes could be avolded in the future. Mureover, revenues from a carbon charge (discussed below) could be used to lower other taxes, while much of the increased spending on oil in the 1973-85 pertod flowed abroad.

Desplte these caveats, the period of the oll shocks provides a useful reference for consideration of the likely impact of $\mathrm{CO}_{2}$ emission-reduction policies on output and productivity growth. Energy remalns a major inpul to the U.S. economy, and studies discussed below suggest that energy price increases at least as large as those experienced between 1973 and 1985 would be required to achieve widely discussed targets for $\mathrm{CO}_{2}$ emissions reduction. On balance, there is no reason to believe that any attempt to reduce energy use significantly today would be substantially less economically disruptive than were the oil shocks of the 1970's.

\section{b. Long-Term Energy and Energy-Economic Policy} Models. These models allow for explicit analysis of policies that raise the price of fossil fuels to discourage their use. The most natural (and casily analyzed) policies of this sort involve imposition of a carbon charge.

A charge levied on the carbon content of primary fossil fuels at their first sale or entry into the distribution system would provide an administratively simple means of reflecting the social undesirability of greenhousc emissions in fossil fucl prices. Because end-users cannot significantly alter the relationship between fuel carbon content and $\mathrm{CO}_{2}$ emlssions, and an economical carbon scrubbing technology is not anticipated th the near future, there is no efficlency advantage in applying the charge to end asers. Sellers in long-term energy contracts. (cspeclally coul contracts) should not be fored to absorb the charge to fullill their existing contructs. This problem can be avolded by Imposing the charge on the buyer in the first transaction. Depending on other nations' mitigation actions, coal destined for export might be exempted from the charge, and a refundable credle for petrochemical and other uses of fossil fucls that sequester veriflable amounts of carbon could be considered. In principle, imports of electrictty generated from fossil fucis should pay a charge based on the carbon content of the input fucl, though this could conflict with our free trade agrement with Canada.

Unlike an ordinary tax, which distorts private decisions such as the cholce between work and letsure, an approprlate carbon charge can actually improve resource allocation and raise welfure by closing the gap between the private and social costs of carbon-emilting activities. A carbon charge would alfect decisions ranging from the choice among alternative technologies for gencrating electricity, to the energy efficiency of cars, bulldings, and industrial equipment, to the demand for autornobile travel and products made from stecl. Because a carbon charge provides incentives that affect decisions at all points along the production-consumption chain and across all industries, it automatically focuses on those activilies where $\mathrm{CO}_{2}$ emissions reductions can be achieved at least cost. The least-cost property of charges when markets work well is useful in placing a lower bound on the economic implications of particular grenhouse gas emissions targets, even If other tools would actually be used for implementation. A carbon charge does not, of course, provide the full flexibility and effleiency of a comprehensive charge system applied across all greenhouse gas sources and sinks. 
Existing economy-wide studies generally imply that carbon charges on the order of $\$ 100$ per ton or more would be necded to have a signiflcant longurun effect on carbon dioxide emissions'. At current prices, and not allowing for fucl market responses, a carbon charge of $\$ 1(X)$ per metrle ton would increase the average price of coal dellvered to electric utilities by 178 percent, the average price of natural gas by 49 percent, and the average price of oil by 70 percent. These impacts are comparable on average to the energy price increases caused by the oll price shocks of the 1970's. Electriclty rates would immediately rise by up to 30 percent, 15 times the average Increase that would to produced by the Adrinistration's controversial actd rain proposals.

Nordhaus (1990a) provides an expllcit (albelt necessarily crude) analysis of the costs and berielits of reductions in greenhouse gas emissions. His highly uncertain polnt estimate of the future costs of warming, based on selected EPA estimates of lis effects on sea level, electricily demand, and agrtcultural productivity is 0.25 pereent of future GNP. Even this small impact is sufficient to justify low cost measures, such as significant curtailment of CFCs and a small $\$ 3$ per ton carbon charge. At the high end the range of effects that is likely to contain the true effect (anywhere from a benefit of 1.75 percent of GNP to a cost of 2.25 percent of (INP), a carbon charge of as much as $\$ 30$ per ton might be justifiable. Both of these estimates are for a real discount rate 1 percent higher than the output growth rate. The optimal taxes are higher (lower) at lower (higher) discount rates. This analysis suggests that if carbon charges are found desirable in pilnciple, serious consideration should be given to using charges substantially lower than those employed in the modeling exercises discussised here. Once a carbon charge system is in place, the rate can be raised-or lowered-as scientifle and economic uncertaintles are resolved in the future.

Manne and Richels (1989) simulate pollcies capable of stabilizing U.S. $\mathrm{CO}_{2}$ emissions at their 1990 level through $20(0)$ and then reducing them to 80 pereent of this level by 2020 . Their polley is a charge that begins at $\$ 29$ per ton of carbon but rises sharply after the year $2(X X)$ before stabllizing at $\$ 2.50$ per ton by tho middle of the century, Intitally, the emissions limit is met by fud switching from coal to natural gas. Natural gas, whlch accounted for 12 percent of electrictly genoration in 1985, aocounts for 27 percent by 2010 . The rapld runup in charge rales after $2(x)(x)$ reflects the difficulty of securing a 20-percent cmissions reduction by $2(20)$ in the face of exhaustion of natural gas supplles and prior to the large-scale deployment of advanced technology altematives to fossil fucls, Costs build to about 5 percent of GNP by 2.030 and maintain that value through 21 ( ).

However, the costs of meeting the emissions larget are signifleantly reduced if the BAEGR turns out to be lower than the 1.7 percent they assume. For example, a 1-percent autonomous (not llnked to prices) improvement in energy efflclency reduces losses to about 3 percent of GNP. The further addition of an optimistic forecast of future energy technology lowers estlmated losses to a little more than 1 percent of GNP.

The autonomous rate of increase in energy effleiency (AEEI), and the cost difference between carbon-producing techmologles and carbon-free replacements are key inputs to the model. Hogan and Jorgenson (1990) argue that, because techrotoglcal advance as a whole has been energy-using rather than cnergy-saving, the AEEI is negallve. Williams (1989, 1990) argues that the avallabllity of low.cost conservation and alternative cnergy technologies implies both a higher AEEI and a much lower reciuled carbon tax than that assumed by Manne and Richels. As noted in Section III.A.3, asserticns that avallable efficiency improvements are cost-saving or nearly costless raise the classic question of why these improvements are not automatically taking place. The availability of low-carbon technologles that were truly attractlve to consumers would, of course, signiffeantly lower carbon emissions in the absence of any policy actlon.

Another Manne and Richels paper (1990) applics the same basic framework on a world scale. The policy 
simulation holds emissions beyond 2020 to 80 perount of 1900 levels in the OECD countries, Eastern Europe, and the Sovict Union. Emissions in China and the developing world are stabilized at twice the present lovel. Autonomous efficiency increases in the OECD and China are set to 0.5 percent and 1.0 percent respectlvely pror to 2050; world wide convergence to a 0.5-percent annual AEEI rate after 2050) is assumed. GDP losses from the carbon construint over the 2030 to $21(X)$ period average 3 percent for the U.S, and 1 to 2 percent for other OECD countries. Eastern Europe and the Sovid Unton losses are slightly higher than those for the U.S. GDP losses for the developing countrles are largest, with China facing GDP losses ranging from 9 1011 percent between 2040 and 2100 .

In an early paper, Edmonds and Rellly (1983) use an' energy policy model to consider the application of carbon charges in the United States alone and to the entire world. These cases may be vlewed as bracketing the outcomes under an international agreement with special provisions for developing countries and/or Incomplete purticipation. The appllcation of stiff carbon fees throughout the world (100) pereent charge on coal, 78 percent on oil, 56 percent on natural gas, and 115 percent on synliuels, roughly reflecting the different carbon contem of the different fuels) beginning in 1985 is found to reduco global carbon emissions by 40) percent from base case levels by 2050 . However, given the high BAEGR employed (2.27 pereent) global $\mathrm{CO}_{2}$ emissions are still three times the current level in 2050. A fee program in the United States alone is much less effective, teducing 2050 global emissions by only 15 percent. Carbon charges in the United States alone depress the world market prices of fosisil fuels. leading to an increase in fossil energy use overseas that significantly off'sets the greenhouse benefits of reduced energy demand and fuel switching in the United States.

In subsecjuent work, Edmonds (1989), Rellly and Edmonds (1985), Reilly, el al. (1987), and others have used the same model with a lower BAEGR. Cline (1989) finds that a somewhat higher global charge (approximately $\$ 100$ per ton of carbon) than that considered In the original Edmonds-Reilly paper is sufficient to stabilize $\mathrm{CO}_{2}$ cmissions at or silghtly below current levels in the second hall of the 21 st century with a 0,95 -pereent world BAEGR. The Congressional Budget Offlec (CBO) analysis of carbon charges (CBO, 1990), forthooming) presents runs with a 2.0 -percent world BAEGR, In these runs, a global \$100-per-ton carbon charge cuts a baseline 35()-percent increase in $\mathrm{CO}_{2}$ emissions by 2050 to a $25($ ) percent increase. The difference between these results and Cline's highlights the Importance of the BAECR in dilving the results regarding effectiveness of taxes in meeting a target emissions level.

Some general observations apply to all runs of this model. First, while some substilution among primary energy sources does occur, the primary mechanism l'or' cutting emissions is a rediction in overall energy use. Second, the burden of greenhouse policy always falls heavily on the coal sector and on net exporters of fossil fucls (and, by implication, energy-Intensive producis), For example, in Cline's runs, coal use increases between 2000 and 2050 in the baseline case but falls by more than two-thirds when the global charge is applled. Third, while global polloles are clearly preferable in $\mathrm{CO}_{2}$ limitation terms, they are likely 10 put much more pressure on the world savings. Investment balance. Crowding out of other productive Investment becomos a larger problem as more countries attempl to increase investment in encrgy efficiency at the sume time. Indeed, for developing countries with limited access to capital markets, concern over crowding out could pose a serious barrier to any particlpation in $\mathrm{CO}_{2}$ limitation efforts. Finally, the Edmonds-Reilly model is not useful for estimating the effects of greenhouse policy on GNP, since the role of energy in the production function and tradeoll's between energy and nonenergy investment are not explicilly modeled.

Ongoing work at the CBO will also report on runs of the Jorgenson general equilibrium model with a unilateral $\$ 1(x)$ per ton carton charge imposed in the year $2000(\mathrm{CBO}, 199)$, forthoming). This policy is estimated to reduce real (iNP by 1 percent. The 
Jorgenson model essentially involves a "de novo". solution that does not take into account constralnt:; Imposed by curtent lixed assets and labor force skllls on the composition of the economy 10 years from now. The Jorgenson model solution entalls radical shifts in the composition of electricity supply and large interindustry shifts in the composition of the economy. Sectors such as textlles, agriculture, and leather grow, while chemicals, mining, and plastlos decline.

Because Jorgenson's model describes an economy in $2000)$ that is very dlfferent from today's economy and because adjustments involve costs, such radical shifts are unlikely to occur over this time interval. Such shifts would necessarily entail significant dislocations. Because of these adjustment costs, actual structural changes and thus actual emissions reductions, would likely be lower than these results indicate. Alternatively, much higher economic costs, including significant labor force dislocations and sharp reductions in the value of existing immobile assets, would be reguired to achieve the level of emissions reduction oblained in the Jorgenson model solution.

The sectoral shifts envisioned by Jorgenson would nonetheless occur over time if significant policies to discourage $\mathrm{CO}_{2}$ emissions were adopted. These large distributional effects are thus a reminder that the aggregate economic effects' of $\mathrm{CO}_{2}$ emissions reduction policies, variously estimated at between 1 and 5 percent of GNP for varbon charges in the $\$ 100$ per ton range, would not be felt evenly throughout the economy.

c. Short-Run Economic/Energy Models. A recent detailed analysis considered the cost to Australia of achieving a 20-percent reduction in $\mathrm{CO}_{2}$ cmissions by 2005 (Marks, et al., 1989). In some respects, such as the significant use of coal in electricity generation, the Australian situation is similar to that of the United States. Using very conservative methodology, attainment of a 20-percent emission reduction is estimated to slow economic growth and cause GNP in 2005 to be at least 1.2 percent below the no-policy baseline GNP levels. Since Australla is a small economy with an open capital market, the investments needed to achicve the emissions target may be possible wilhout driving up interest rates or crowding out other investment.

Short-run economic modeling for the U.S. economy shows that a carbon charge of $\$ 100$ per ton would have a signllicant effect on both $\mathrm{CO}_{2}$ cmissions and economic growth rates even if it were phased in over a 10-year period (CBO, 1990, forthcoming), One widely used macroeconometric model shows a depression of 2 percent in real GNP from bascline levels over the next decade; effects on the overall price level are approximately 2 percent during the phase-in period.

The same study notes that the transition could be much more difficult if carbon charges were imposed suddenly. This is true even if the full amount of the carbon charges was retumed to the economy through reductions in other taxes. (At 1988 energy consumption levels, a $\$ 100$ charge would raise approximately $\$ 130$ billion annually, However, additional debt service costs and higher federal expenditures for cyclically sensitive programs would almost fully offset this additional revenue in the near term.) Reductions in other taxes would lose some of the $\mathrm{CO}_{2}$ reduction benefits associated with a weaker economy.

Morris ct al, (1990) use a linear programming model to consider the potential for short-term $\mathrm{CO}_{2}$ reductions in the United States. Energy-saving technologies are applied based on enginecring estimates of their cost-effectiveness (comparing higher initial cost and lower operating cost) evaluated at a 7-percent real discount rate. Many low- or no-cost technologies are identifled using this criterion, which does not consider other relevant product attributes. Some of these technologies, such as improved insulation retrofit options, represent one-time reductions-emissions growth continues from a lower base once they are installed. All chosen technologies are assumed to be applied from 1985 onwards, but no mechanism for implementing the technologies selected by the model either prospectively (or retrospectively) is identified. 
The marginal cost of a 20-percent reduction in emissions from 1990 levels, assuming significunt new investment in nuclear power, is $\$ 39$ per ton. Without new nuclear power, the marginal cost of a 20-percent reduction is $\$ 130$ per ton.

d. Energy Sector Impacts. Because coal is at the same time this country's (and the world's) most abundant fossil fuel, as well as the fossil fuel with the highest carbon emissions per unit of energy, it is impossible to construct a plausible scen.rio for substantial $\mathrm{CO}_{2}$ emisisions reduction without a major adverse impact on the coal industry.

The Department of Energy provided some rough calculations of possible impacts. They find that halving $\mathrm{CO}_{2}$ emissions growth could produce a 25 -percent decline in coal industry employment (relative to baseline assumptions) by 2025 , while stabilizing emissions could require a 40-percent decline over this 35-year period. Global commitment to a 20 percent emissions cut could lower employment by about half; unilateral OECD commitment to this global goal would eliminate the U.S. coal industry, as would global or OECD-only commitment to a 50-percent reduction in $\mathrm{CO}_{2}$ emissions.

It is important to recognize, however, that elimination of coal-mining jobs gradually over time does not necessarily imply increased general unemployment, in the case of an expanding economy though there may be persistent regional problems. A shift to other energy sources would create jobs. In the short run, jobs will likely be created in the natural gas industry. In the longer run, three regional studies of biomass energy use sponsored by the Department of Energy's Regional Biomass Encrgy Program (Council of Great Lakes Governors, 1985; Chamberlin and High, 1986; Tennessec Valley Authority, 1989) suggest that a shift from fossil to biomass energy would on balance create jobs. Similarly, a study conducted for the California Energy Commission (1986b) suggests that renewable energy technologies are generally more labor-intensive than oil and gas.

\section{Regulatory Adjustments}

There are a number of reasons why total $U_{S} S$, investment in energy efflciency may be suboptimal. First, many costs associated with the production, transportation, and conversion of fucls-iricluding alr and water pollution, storage of nuclear wastes, and reduced energy security-are not fully reflected in retail prices for fuels and electricity. Second, electricity prices tend to be based on average cost rather than on marginal cost, which is often higher. Third, it is often difficult for buyers to acquire or analyze information on available energy-efficiency options. It has been argued that this difficulty leads industrial buyers to ignore energy use implications of relatively small purchases-such as lighting. Similarly, since it is difflcult to estimate future utility bills, it has been argued that builders and homeowners tend to focus excessively on the initial capital costs of appliances and space heating systems, rather than on discounted life-cycle costs. At least one often-cited econornetric study (Hausman, 1979) finds that, consistent with this hypothesis, consumers act as if they have abnormally high discount rates when making appliance purchase decisions.

Based on these and related arguments, and on studies that suggest that cost-effective conservation could reduce U.S. energy use by 20 percent or more (Pirkey and Scheer, 1988), many analysts have called for a variety of reguiatory initiatives to increase the efficiency of energy use and, thereby, to reduce $\mathrm{CO}_{2}$ emissions.

a. Reform of Electric Utility Ratemaking. It must be understood at the outset that average cost is not always below marginal cost and that clectricity prices are not always set by simply averaging costs. The prospect of self-generation by some large industrial customers, in particular, may serve to keep industrial prices nea* marginal cost.

The literature on this issue is thin, but a recent study by Wenders (1986) provides an instructive empirical analysis of electricity prices charged by five major utilities throughout the United States. Using 1980 and 1981 data, he finds that prices were on average below marginal cost, but the pattern of deviations from marginal cost was complex. Prices were above (long-run) marginal cost in peak periods and below 
marginal cost otherwise; residential prices were below marginal cost, while some utilities charged commercial and industrial customers prices above marginal cost.

This complexity, the likelihood that price elasticities vary by customer class and between peak and off-peak periods, and the variability of rate structures within Wenders' small sample suggests that the elimination of electricity pricing distortions would be as likely to yield increases in consumption and emissions as decreases-though such reform would on balance improve resource allocation.

b. Utility Demand-Side Management. Many analysts have called for reform of electric and gas utility regulation to give utilities incentives to remove impediments $\therefore$ efficient investments in energy conservation. The basic rationale is that existing regulation discourages utilities from promoting energy efficiency, because lower demand generally reduces eamings, and that there are information-related entry barriers to third-party providers of "energy services" (Moskovitz, 1988). Two approaches to reform have been widely discussed.

The first approach is to permit utilities to increase their earnings by making cost-effective investments in conservation-even if those investments are on their customers' premiscs. Programs of this sort are newly in place or under development for eight New England electric utilities, which account for about 75 percent of the region's power demand (Foy, 1989). A key feature of these efforts is close attention to evaluation and monitoring; this should result in a rapid accumulation of useful data. Based on preliminary experience, the Conservation Law Foundation estimates that programs of this sort could reduce annual U.S. anthropogenic $\mathrm{CO}_{2}$ emissions by between 0.7 and 0.8 percent (Foy 1989, 1990).

A second, complementary approach is to integrate conservation into the competitive bidding process for meeting new electricity supply requirements, which has been adopted in 18 States and is under active consideration in at least 15 more. Cicchetti and Hogan (1989) describe an economically efficient approach to doing this; sec also Joskow (1990). The beginnings of such a comprehensive program can be found in such diverse States as Maine, Massachusetts, New York,
California, and Wisconsin. Bidding sclection criteria could also include environmental externalities to allow environmentally clean projects to compete favorably with lower cost but less environmentally attractive proposals. A step in this direction has recently heen taken in the New York State Energy Plan (1989).

While the desirability of regulatory changes of thesc sorts is apparent, estimates of potential achievable savings of electricity range from 4 percent to 75 percent. Industry sources such as the Electric Power Research Institute (1989) estimate potential savings of 20 percent between 1977 and 2010. The uncertainty surrounding these estimates is evident from the size of the range. According to the Northwest Power Planning Council, which has extensive experience in demand-side efforts, hard quantifiable experiences are extremely limited." The New England efforts discussed above may remedy this in a few years.

c. Research and Information. During the past 8 years, DOE's R\&D budgets for end-user energy-efficiency improvements have declined significantly. DOE's 1989 conservation budget in constant dollars is less than a third of its 1980 level. However, DOE's budget for supply efficiency has increased. As a proportion of the total national energy R\&D budget (including expenditures by DOE, NRC, EPRI, and GRI), energy efficiency accounts for only 9 percent. Expanded funding would permit DOE to work more closely with industry to demonstrate new energy-efficient technologies, assess the long-term performance (durability) of energy-efficient technologies, and revive research on the patterns and determinants of energy-related decisionmaking and the barriers to adoption of energy-efficiency actions.

Similarly, funding for DOE programs that provide financial and technical assistance to States has decreased by two-thirds in recent years. (These programs include the State Energy Conservation Program, the Energy Extension Service, and a small Least-Cost Utility Planning Program.) There are a number of areas where DOE could sponsor demonstration of energy-efficient equipment and work with trade associations to encourage dealers to stock energy-efficient systems and building managers to install them. 
d. Building and Appliance Standards. Experience with energy-efficiency standards throughout the country (especially in California and the Pacific Northwest) shows that they can reduce energy consumption, and thus $\mathrm{CO}_{2}$ emissions. If imposition of Federal standards is deemed inappropriate, DOE could assist State and local governments on code development and training and could assist builders on design and construction techniques aimed at cost-effective conservation. These and related objectives would be furthered by increasing DOE's budget for building standards and guidelines, currently only $\$ 700,000$ a year.

The National Appliance Energy Conservation Act of 1987 requires DOE to review appliance efficiency standards on a regular basis and to promulgate more stringent standards where technically and economicaliy feasible. The pace of the statutorily required review could be accelerated. DOE could also review the feasibility of expanding efficiency standards to other products, including incandescent and fluorescent lamps. However, as noted above, incentives or direct correction of market failures provide attractive alternatives to the imposition of command-and-control standards.

e. Transportation. The corporate average fuel economy law was enacted in 1975 and established a fleet-average goal of $27.5 \mathrm{mpg}$ for 1985 and beyond. That goal has been achieved, and the average fuel economy of the new car fleet has been quite stable at around $28 \mathrm{mpg}$ for several years. Increases in fuel economy have produced essentially proportional reductions in $\mathrm{CO}_{2}$ emissions per vehicle mile. The CAFE program is controversial and was opposed by the previous Administration, though the standard was increased by this Administration in the spring of 1989.

Further increases in the CAFE standard are technically feasible and would likely reduce $\mathrm{CO}_{2}$ emissions; estimates of the costs of such increases are controversial. It seems clear that widespread use of currently available and likely future technologies would permit increases in the average fuel economy of the new car flect without reducing performance below recent levels (but perhaps below levels planned in the absence of tighter CAFE standards). The Office of Technology Assessment (OTA) (Plotkin, 1989) considered standards in the $32-1033-\mathrm{mpg}$ range for model year 1995 to be feasible in this sense. The Department of Energy (Stuntz, 1989) points to a 29- to 31 -mpg range for that year, and $36 \mathrm{mpg}$ by 2000 . The OTA cstimates that by 2010 a $33-\mathrm{mpg}$ standard would reduce U.S. fossil fuel $\mathrm{CO}_{2}$ emissions by 0.5 percent (and world emissions by 0.1 percent) and U.S. fuel use by 5 percent. Oil imports would also be cut.

The difficulty of assessing the costs and benefits of increases in the CAFE standard was discussed in Section III.A.3, above. Benefits will be reduced if higher prices than would otherwise obtain reduce new car sales and thus slow the improvement in fleet-average economy. Benefits will also be reduced if lower per-mile costs lead to more miles per car. Cost anal 'sis must also consider impacts on diverse consumers, not just on national averages, and must take into account foregone performance improvements as well as the reductions in safety and spaciousness that could occur if manufacturers meet higher standards in part by downsizing. Since fuel economy labels provide good information, it is not clear that CAFE standards would remedy any market failure that could not be addressed more efficiently by employing a carbon charge or gasoline tax.

f. Agricultural Policy. A number of changes in agricultural programs that would have other benefits can be expected to assist in reducing emissions of greenhouse gases. These include reducing commodity price support levels, encouraging additional tree planting, and conservation cross compliance.

This and the preceding Administration have sought to reduce price support levels for program crops in order to increase the efficiency of resource use within the agricultural sector. Reducing agricultural subsidies will tend to reduce total acreage in program crops and change the mix of crops grown. Com and wheat, the two most widely grown program crops, account for 57 percent of nitrogen fertilizers used. As is discussed in Section III.E, below, the use of these fertilizers is associated with emissions of $\mathrm{N}_{2} \mathrm{O}$, a greenhouse gas with a relatively high radiative forcing index. Reducing income support can be expected to reduce the acreage devoted to com and wheat and, possibly, to increase the acreage devoted to soybeans, which fix their own nitrogen from the air. In addition, reducing income 
support is likely to reduce per-acre use of all inputs, including nitrogen fertilizers (Miranowski et al., 1989).

Reducing agricultural support prices should also slow the rate of conversion of forest and woodlands to cropland. It should also encourage the conversion of marginal cropland into forestland, particularly in areas where commercial forestry opportunitics exist. This could result in a significant increase in $\mathrm{CO}_{2}$ removal from the atmosphere. The key point is that less support would allow farmers to respond to market changes induced by climate change.

Conservation Compliance denies farm program payments to farmers who cultivate highly erodible land who fail to have a Soil Conservation Service approved conservation plan by 1990 or fail to fully implement the plan by 1995 . These plans for the most part require the use of conservation tillage, which reduces mechanical soil preparation and mechanical cultivation. Consequently, the number of tractor passes through the field and the total tractor operating hours per acre are reduced. This should result in a reduction in $\mathrm{CO}_{2}$ and $\mathrm{N}_{2} \mathrm{O}$ emissions. But it also could mean increased use of herbicides and pesticides, leading to other potential problems.

\section{New Technologies}

This section considers the role of advanced technology in reducing $\mathrm{CO}_{2}$ emissions in the electric generation and energy end-use sectors. Of particular interest is how much can be gained by broader use of currently available technologies that enjoy only limited commercial use because they are new and/or expensive, as well as advanced technologies that only require modest additional development for widespread application. While new technologies offer significant $\mathrm{CO}_{2}$ emissions reduction potential after 2000, there is no simple "technological fix" to this problem. Regulatory barriers may affect the economics and introduction of some technologies.

At any given time, a combination of technological, behavioral, market, regulatory, and macroeconomic factors interact to determine patterns of energy use, the introduction of new technologies into widespread acceptance, and the further deployment of technologies already in usc. Even in the analysis of high-quality historical data, it is difficult to identify the portion of actual energy use that is due to any single causal factor, including new technology. Thus the discussion below can only be indicative of the likely role of new technology; further research may well change its conclusions.

Progress in reducing $\mathrm{CO}_{2}$ emissions depends on installing and using new technologies in a host of applications. Key determinants of the penetration of new technologies are sectoral rates of growth ard average economic lifetimes of capital assets. Lifetimes vary considerably, from motor vehicles (8 to 14 ycars) to residential (30 to 80 years) and non-residential (31 to 48 years) structures. Electric generating equipment (10 to 55 years), other transportation equipment (16 to 28 years), and industrial equipment (14 to 27 years) have intermediate lifetimes. Moreover, it can take years for economical new technologics to become accepted. Thus new energy technologies may not come into widespread use even in new installations for years-or even a decade or more-after they are commercially available.

a. Electricity Generation. By 2010 an estimated 400 gigawatts $(\mathrm{GW})$ of new electric generating capacity may be needed to meet demand increases and to replace existing capacity that will retire. New technologies can, therefore, play a significant role in limiting $\mathrm{CO}_{2}$ emissions from new electric generating sources. But it must be recogrized that only $65 \mathrm{GW}$ of this total will replace retired capacity; about $655 \mathrm{GW}$ (91 percent) of existing capacity will not retire until after 2010. $\mathrm{CO}_{2}$ emissions may also be reduced as existing generating units are repowered and reboilered with more efficient technologies or with equipment designed to burn fuels with lower carbon content.

A variety of new technologies that produce electricity from coal oil, natural gas, and methane with improved efficiency in the conversion of fossil energy into electrical energy are in various stages of development. By reducing the amount of fossil fuel burned to generate a given amount of electricity, these technologies can reduce $\mathrm{CO}_{2}$ emissions per unit of electricity produced. Renewable resources, primarily hydropower and wood, provided 8 percent of the nation's energy in 1988. Newer renewable resource technologies, including wind, solar thermal electric, geothermal electric, photovoltaic, and biomass 
technologics, will make increasing contributions in coming decades.

The future use of nuclear power both worldwide and in the United States will continue to depend on many factors, including relative cost, national security considerations, third world development, progress in dealing with nuclear waste disposal and nuclear weapons proliferation, continued safe operation of existing nuclear plants, and establishment of a stable and certain licensing process. The goal of the DOE nuclear reictor program is to develop nuclear reactors with simplified and standardized designs and passive safety features, designs which hold the promise of revitalizing the nuclear power industry through the simplification of the licensing process and resulting reduction in costs and financial risks. In addition, ail NRC rulemaking procedure is in place to preapprove standardized nuclear plant designs so that parties interested in purchasing a plant have assurance that there will be no intractable licensing problems. Final designs will be ready for demonstration or commercialization in the 1990's and, if public attitudes and regulatory changes reduce business risks, the next generation of reactors may come into use after 2000.

On balance, while important gains in generation efficiency are possible, they are not likely to penetrate the market substantially in the near term based on market forces alone. The potential for advanced technology to reduce generation-related $\mathrm{CO}_{2}$ emissions appears to increase substantially after 2000, but this potential has wide uncertainty bounds.

It is technically possible to "scrub" carbon from combustion waste gases, but it is very expensive. One study concludes that collection and disposal of powerplant $\mathrm{CO}_{2}$ emissions would at least double the cost of coal-fired electric power (Steinberg, 1983). There has also been some discussion of methods of utilizing only the hydrogen in fossil fuels (Steinberg and Cheng, 1987). These ideas are in their infancy and are many years away from commercial application.

b. Energy End-Use Technologies. Many estimates of conservation potential indicate that new technologies could produce significant savings over expected energy use, even by the year 2000). These estimates are buttressed by analysis of historical data, which indicates that over the 1972-86 period, technology improvements have played particularly signifteant roles in reducing energy use in all sectors, particularly industrial and transportation but also including commercial and residential buildings.

The contributions from new technology to energy-efficiency gains are potentially substantial, particularly after 2010. Of course, the eventual levels of application depend heavily on fucl prices and the cconomic lifetimes of capital stock. Because of lower lifetimes, the prospects for near-term stock turnover are highest for transportation vehicles, appliances, and some light industrial equipment. Most residential, commercial, industrial and utility structures and large equipment technologies require much longer time periods to be replaced.

On balance, advanced energy use technology seems to have the potential to contribute significantly to reducing $\mathrm{CO}_{2}$ emissions, but estimates of the extent of the contribution vary widely. For example, a recent study (EPRI, 1990) found that instantaneous replacement of the entire stock of electric end-use equipment with the most energy-eflicient alternatives available could reduce electricity use by 24 to 44 percent from projected levels in the year 2000 . Exclusion of technologies that are not cost-effective and relaxation of the instantaneous replacement assumption, which does not scem to approximate any feasible policy, would significantly change these estimates. Most energy projections indicate that energy efficiency gains on the order of 12 percent can occur by 2010 through the operation of markel forces if fuel prices rise as projected. Substantial additional gains in energy efficiency could occur by more widespread application of "best practice" technologies, but extensive policy interventions or much higher fuel prices are essential to achieve them. Significant technical potential for efficiency improvements and fuel switching beyond 2010 exist, but increased efforts to develop and commercialize new technology are required in the near term to achicve these gains.

\section{Forestation}

Reforestation and afforestation policies may remove $\mathrm{CO}_{2}$ from the atmosphere and store the carbon in the woody parts of living trees. By preventing the release of such carbon, policies that limit deforestation reduce 
net emissions of $\mathrm{CO}_{2}$. However, reforestation may affect microclimates and the soil's ability to absorb $\mathrm{CO}_{2}$. As a forest grows, an annual flow of carbon is removed, but it is generally assumed that carbon release from decaly balances carbon uptake from new growth in mature forests. Reforestation is a (comparatively) short-term approach that may cause a substantial decrease in net $\mathrm{CO}_{2}$ einissions for three to five decades (Sedjo and Solomon, 1988). After this period, a large effort would be required to keep the absorbed carbon sequestered. However, even short-term sequestration could allow time for the development and adoption of new technologies that emitted less carbon, possibly including the substitution of timber-based fuels for fossil fuels to create a zero net carbon energy cycle with continuous replanting.

a. Cost Analysis. Sedjo and Solomon (1988) provide cost estimates for a global reforestation plan designed to sequester the entire flow of net additions of carbon to the atmosphere. Carbon absorption is highest for recently planted fast-growing species on tropical sitcs. Plantations with these characteristics are estimated to sequester 2.3 metric tons of carbon annually per acre. If such sites were used, an estimated 1.1 trillion acres of land would be required, while if slower growing trees were planted on sites in temperate zones, over 7.4 trillion acres would be required. These are large requirements; 1.1 trillion acres is 50 percent greater than the current forested area in the United States and more than 15 percent of the forested areas in the world. A forestation program on this scale would require a world wide search for suitable and inexpensive land.

Estimated total costs of absorbing global net carbon emissions range from $\$ 372$ to $\$ 697$ billion. Based on total program costs and assuming a 30-ycar rotation, the cost ranges from $\$ 4.29$ to $\$ 8.03$ per metric ton of carbon removed. In addition, future harvest of the large quantity of trees required for significant carbon sequestering could disrupt timber markets and dramatically reduce incentives for planting on private forestland.

Moulton and Richards (1989) cxamine a more modest carbon sequestering program in the United States. They conclude that marginal cosis per-ton range from $\$ 17.71$ to $\$ 102.63$ per metric ton depending on program size. The lower estimated per ton costs for the larger worldwide sequestering program flow from more optimistic assumptions about both carbon absorption and land costs. These assumptions may be justifled on the avaliability of less expensive land outside the United States and faster forest growth rates on tropical sites. However, the smaller program with more pessimistic assumptions is probably a more reliable guide to costs for U.S. reforestation programs.

Forestation programs of moderate size can be implemented in a wide variety of ways to minimize impacts on land costs. Several options have been outlined by the U.S. Forest Service (1989), including voluntecr urban tree planting programs, cost-sharing and technical assistance programs, and land leasing programs. For example, enhancing forest growth on sparsely forested land would not increase competition for land but would increase carbon uptake. Urban tree planting would not raise land costs and, by providing shade, may reduce fossil fuel consumption by reducing demand for air conditioning. Land leasing forestation programs or programs that only involve cost sharing in the costs of planting, improving, and managing lands for timber production are two alternatives for increasing forestation on private nonurban land. On a large scale, such programs could reduce expected stumpage prices and thus lead to reduced forestation in current commercial forests.

The net ecological and recreational benefits of forestation would depend on the type of forest planted and the current use of the land. All types of forest would tend to have soil erosion benefits when established on erodible cropland. However, fast-growth forest plantations, with repeated harvest of small trees for fiber or energy, would have few recreational benefits and offer habitat for limited species of wildlife. Frequent harvests and replanting of fast-growth stands might result in added crosion if such forests replaced natural forest land or grasslands. Grassland, sparse forest land, mixed-use forest (including grazing use), and old growth forests offer diverse and unique wildlife habitats and ecosystems. Because the greatest intake of $\mathrm{CO}_{2}$ occurs in young, fast-growing stands, enhancing the carbon storage properties of land in such current uses would dramatically change the ecosystem, and widespread 
forestation with the sole goal of carbon storage could significantly decrease biodiversity.

b. Management. Because new forests represent a growing stock of carbon, the efficacy of forestation as a carbon management tool depends importantly on how the stock of accumulated carbon in mature forests is managed. If new forests are allowed to mature, significant carbon removal would occur only over a 30 to 40 year period. To continue carbon removal through forestation would require forest establishment on increasingly large areas of the Earth's surface.

If forest land is cleared for other uses in the future, the carbon stored during forest growth is then released to the atmosphere. If forest carbon is somchow stored so that decay and release to the atmosphere does not occur, a continuous flow of carbon can be removed. (Solidwood products are estirnated to contain only about 0.5 percent of the carbon in living trees, however (Rotty, 1986).) More plausibly, forests might be used as an energy source. In this case, net carbon removal would oceur while new forest growth is established, and a continuing carbon reduction benefit would occur to the extent that biofuels replaced fossil fuels. Since biomass and other renewable energy programs can also produce large demands for land, analysis of alforestation programs requires careful coordination with energy system analysis.

Each of these management options has quite different effects on economic cost and on carbon removal. Unfortunately, the costs and carbon removal benefits of these options have not been systematically analyzed.

\section{Methane}

Methane accounted for about 19 percent of the increase in radiative forcing in the 1980s. The rise in atmospheric $\mathrm{CH}_{4}$ concentrations over the last century is due to a relatively small imbalance between sources and sinks. Current assessments indicate that atmospheric stabilization will require only a 10 - to 20-percent reduction in annual emissions.

As Table 1.3 showed, the developed countries account for only about 25 percent of anthropogenic $\mathrm{CH}_{4}$ cmissions, in part because over half these emissions are produced in agriculure. Thus significant, cost-effective reductions in $\mathrm{CH}_{1}$ emissions will reauire global action. While a number of approaches to controlling these emissions are available, no systematic policy design or costing analysis seems to have been performed. There are ongoing efforts within the Administration to betler quantify the costs of methane reductoms and to develop, refine, and demonstrate best management practices within the areas discussed below: animal waste, coal mining, landfllls, livestock, and rice.

\section{Animal Waste}

Animal wastes are estimated to generate atout 4 percent of anthropogenic $\mathrm{CH}_{4}$ emissions. In developed countries, where these wastes are managed in lagoons, the most promising technology for abatement of this methane is decomposition in anaerobic digesters to produce methane gas, which, like natural gas, can be used to produce electricity and/or shaft power or be bumed in boilers as a heat source. This approach is most promising at sites with large animal herds such as feedlots and dairy farms. Full recovery at these sites would reduce these emissions by over 50 percent. USDA estimated in 1978 that approximatcly 50 million tons of "economically collectable" livestock and poultry residue, when converted through anaerobic digestion, could generate $\mathrm{CH}_{4}$ equal to 7 percent of the natural gas consumed in the United States in 1988.

Fewer than $1(x)$ anaerobic digesters currently are operating on farms in the United States, however. Most of these are producing electricity to power farm equipment. Excess electricity often is sold to the utility grid system. Poor economics, management problems, and infrastructural barriers have restricted widespread adoption of this technology. Most of the plants are one of a kind and expensive. Typical costs of electricily generated are 5 to 7 cents per kilowatthour (k Wh). Additional research should enable the development of standardized facilities that are substantially cheaper and more efficient. Currently, farmers receive 2 to 3 cents per $k$ Wh for electricity they provide 10 utilities except in a few areas, notably California where 9 to 11 cents per $k$ Wh is paid. Many power companies are reluclant to accept power from farmers and establish major road blocks adding to the cost of an intertic. 


\section{Coal Mining}

Methane from coal mining is estimated to contribute 13 percent of anthropogenic emissions. This methane is plpeline quality and can be recovered as a resource, thereby both reducing $\mathrm{CH}_{4}$ emissions and use of other fossil fucls. It is technically feasible to reduce 60 percent of these methane emissions through premining degasilication. This recovery would be performed at a limited number of sites, since about 10) percent of the world's mines generate most of the methane. These mines are concentrated in the 9 countrics that produce the bulk of the world's coal.

Economic assessments show that methane recovery can be profitable with existing technology. Indeed, several recovery operations are running profitably in the United States, An important limitation to more recovery in the United States is that gas companies typically own the rights to the mothane in coal mines. The coal companies can only profit from methane recovery by buying rights to this methane or setting up some sort of joint venture operation.

Preliminary assessments also show that mining methane could be profitable in countries such as China and Poland. For example, analysis suggests that it is less expensive for China to derive energy from mining methane than coal. Much of China's coal is deep-mine coal that is expensive to bring to the surface, and gas pipelines are less expensive to build than the railroads necessary to transport the coal. Despite these analyses, methane mining has not been implemented on a large scale, and a continued rise in coal mining activity is planned to meet China's growing energy needs. Since the USSR, China, East Germany, and Poland are major coal producers, transfer of methane recovery and methane mining technologies to these countries could produce substantial benefits.

\section{Landfills}

Landfills, mainly in developed countries, are estimated to contribute 10 percent of anthropogenic $\mathrm{CH}_{4}$ emissions. Of the 6,584 municipal solid waste landfills in the United States, only 123 (1.9 percent) now recover methane for energy use. Under current market conditions, methane recovery is only viable for large sites with a suitable gas user nearby or at which electricity can be generated and sold into the grid. Regulatory barricrs also exist in many areas. Ongoing research alms at enhancing the economic viability of methane recovery.

EPA hopes to promulgate regulations limiting $\mathrm{CH}_{4}$ emissions from large landfills in the United States. EPA believes that these regulations have the potential to reduce total anthropogenic $\mathrm{CH}_{4}$ emissions by about 1.5 percent. Controls applied in other countries could produce further reductions.

\section{Livestock}

Livestock generate about 20 percent of anthropogenic $\mathrm{CH}_{4}$ cmissions. Intensive (grain-fed) animal production systems used in developed countries result in signiflcantly less methane per unit of output than do extensive (grass-fed) systems prevalent in developing countries. Production methods that enhance efficiency of livestock enterprises also reduce methane emissions per unit of output. Through changes in diet and management of smaller herds due to increased productivity, emissions may be reduced by 2.5 to 75 percent. Other options for methane reduction include increased use of hormones and lower price supports. The costs of these changes will be small.

In developing countries, many of the cattle are nutrient deficient. By supplying nutrient supplements, methane emissions can be reduced, but the costs and potential benefits of this approach are not well understood. In general, while it is possible to reduce methane emissions from intensive livestock production systems, relative gains will be small and may not be achieved without significant technological advance. Further development of best-practice livestock management systems and diffusion of those systems into practice seem the most promising steps in this area.

\section{Rice}

Rice cultivation accounts for about 34 percent of anthropogenic $\mathrm{CH}_{4}$ emissions. Recent work shows that methane emissions may be reduced by decreasing use of animal manures as fertilizer, but there is still considerable uncertainty regarding the cost and volume of reductions that can be achieved in this manner. 


\section{Chlorofluorocarbons and Related Substances}

Chlorofluorocarbons accounted for about 14 percent of increased radiative forcing in the 1980s. In the absence of any control measures, CFCs would account for a much larger share of future increases. However, the Montral Protocol on Substances that Deplete the Ozone Layer represents a commitment to significant controls. While primarlly almed at limiting CFCs and halons because of the threat they pose to the ozone layer, this treaty also results in substantial benefits in terms of grecnhouse gas emissions. The Montreal Protocol has now been ratified by 49 nations and the European Community. These nutions account for over 90 percent of the global consumption of CFCs.

In response to recent scientific evidence that the risks of ozone depletion from CFCs and other ozone-depleting substances are greater than previously thought, the Protocol was amended in June 1990 to expand its coverage to additional ozone-depleting substances and to provide for the complete phaseout of CFCs by $20(0)$. The CFC phaseout will significantly reduce the increase in radiative forcing in the next century.

Significant tecinological advances made during the past several ye ars make such a phaseout feasible. In the near term, substantial emission reductions are being achieved through increased recycling and improved housekeeping (particularly by electronics companies in their use of CFC-113). Development of chemical and process substitutes has also progressed rapidly and has allowed major firms and industries to establish goals for eliminating their use of CFCs ahead of the likely Montreal Protocol schedule. For example, IBM and AT\&T have a phaseout goal by 1994 and the electronics industry as a whole, through its major trade association, has established the goal of an 80 percent reduction by 1997 and a phaseout by 2000). Similarly, the rigid foam insulation industry has established a goal of a complete phascout by 1995 .

The costs of eliminating the use of CFCs and halons will be approximately $\$ 3$ billion over the next ten years (1989 dollars, discounted at 5 percent). These costs could be substantally reduced, along with $\mathrm{CO}_{2}$ emissions, if industry can move to more onergyeffictent refrieserants. For example, if the use of HFC-152a as a refrigerant proves acceptable, cost suvings from improved energy efficiency could reduce the costs of a phaseout in these applications by 57 percent over the next 10 years, EPA and other agencies are working with several industry groups to examine lechonologteal, environmentil, and insiltutional issues related to the use of a wide array of more energy-efficient, low-greenhouse allematives.

\section{E. Nitrous Oxide}

Nitrous oxide accounted for about 5 percent of the increase in radiative forcing in the 1980s. As Section I noted, data on sources of $\mathrm{N}_{2} \mathrm{O}$ cmissions are quite poor. The primary anthropogenic source seems to be the use of nitrogenous fertilizers, which is increasing at 1.3 pereent per year in industrialized countries and 4.1 pereent per year in developing nalions.

From the point of view of policy design, it is unfortunate that the nitrogen content of fertilizer is not the primary determinant of $\mathrm{N}_{2} \mathrm{O}$ cmissions, Emissions of $\mathrm{N}_{2} \mathrm{O}$ vary by one to two orders of magnitude among different types of nitrogenous fertilizers. Other factors affecting emissions include the rate and timing of fertilizer application, the placement of fertilizer (decp or shallow), water management (particularly in rice cullivation), tillage and herbicide use, and the use of legumes as a nitrogen source. No systematic attention seems to have been devoted to the design or cost of policies to reduce $\mathrm{N}_{2} \mathrm{O}$ emissions from fertilizer use or other sources, in part because the relevant scientific base is weak, though some of the agricultural policy changes discussed in Section III.B.2.g., above, would likcly reduce $\mathrm{N}_{2} \mathrm{O}$ emissions from U.S. farms.

New technologies that improve fertilization efficiency also tend to reduce $\mathrm{N}_{2} \mathrm{O}$ emissions, but little appears to be known about their cost-cffectiveness. Advances in blotechnology, particularly the development of weed-resistant crop varieties and nitrogen-fixing cereal crops, may reduce $\mathrm{N}_{2} \mathrm{O}$ emissions in the future. 


\section{BIBLIOGRAPHY}

\section{Asterisks indicate sources cited in the text.}

Ahuja D.D. Tirpak and W. Pepper, 1990. "Relative Contributions of Developed and Developing Countries to Global Warming," to be presented at the International Conference of Energy Economists, New Delhi, January.

Bamola, J.M., D. Raynaud, V.S. Korokevich, and C. Lorlus, 1987. "Vostok Ice Core Provides 160,000)-Year Record of Atmosphertc $\mathrm{CO}_{2}$, " Nature, Vol. 3.

Basheda, G. ot al., 1989. "Congressional Greenhouse Initiative Special Study: Utillty Sector," Argonne National Laboratory: Argonne, IL.

Blake, D.R., and F.S. Rowland, 1988. "Continuing Worldwide Increase in Tropospheric Methane, 1978--1987," Sclence 239:1129-1131.

Boyd, G. et al., 1989. "Congressional Greenhouse Initiative Special Study: Industrial Sector," Argonne National Laboratory: Argonne, IL.

, et al., 1989. "Techrology Characterizations and Policy Options to Reduce GHG Emissions: Fossil Energy Supply Sectors," Argonne National Lahoratory: Argonne, IL.

, et al., 1989. "Technology Characterizations and Policy Options to Reduce GHG Emissions: Industrial Sector," Argonne National Laboratory: Argonne, IL.

Broadus, J.M., 1989. "Possible Impacts of and Adjustments to Sea Level Rise: The Cases of Bangladesh and Egypt," in T. Wigley and R. Warrick eds., "The Effects of Climate Change on Sea Level, Scvere Tropical Storms and their Associated Impacts," University of East Anglia, Norwich, U.K.

California Energy Commission, 1982. Cogeneration Handbook, Callfomia Energy Commission P5(00-82-054, Sacramento, CA.

California Energy Commission, 1986a. Biomass Energy Report, Senate Bill 771, report mandated by the State Agricultural and Forestry Residue Utilization Act of 1979.

*Califomia Energy Commission, 1986b. "Solar and Wind Technology Tax Incentive Impact Analysis." Consultant Report, May.

Carl, M.E. et al., 1987. "Energy Conservation Potential: A Review of Eight Studies," Energeties, Inc., Columbia, MD.

Carlsmith, R.G. et al., 1989. "Energy Efficiency: How Far Can We Go?," U.S. Department of Encrgy, Washington, DC. 
Cavanaugh, Ralph, Chris Calwell, David Goldstein, and Robert Watson, 1989. "National Encrgy Pollcy," World Pollcy Journal, Spring.

*Chamberlin, R., and C. High, 1986. "Economte lmpacts of Wood Energy in the Northeast." Council of North East Govemors Pollcy Research Center, April.

Chandler, J., 1982. "Development of Blogas Systems for Agriculture in Callfornia," paper presented to the Joint United States/China Blomass Conversion Technologies Symposium, Chengdu, Slchuan Province, November 29.

Chandler, J,A., et al., 1983, "A Low Cost 75kW Covered Lagoon Blogas System," paper presented to Energy from Blomass and Wastes VII, Lake Buena Vista, FL, January 25.

Chandler, William U., 1989. "Assessing Carbon Emission Control Strategles: The Case of China," paper presented at a Workshop on Energy and Environmental Modeling and Policy Analysis, MIT Center for Energy Policy Research.

, 1988. "Energy Efficlency: A New Agenda," Amertcan Council for an Energy-Efflelent Economy, Washington, DC.

Choucri, Nazil, 1989. "The State System and the Global Environment: Interactions Among Population, Resnurces, Technology." paper presented at a Workshop on Energy and Environmental Modeling and Policy Analysis, MIT Center for Energy Policy Research.

*Cicchettl, C.J., and W. Hogan., 1989. "Including Unbundled Demand-Side Options in Electric Utility Biddling Programs," Public Utilities Fortnightly, June 8.

Cicerone, R.J., and R.S. Oremland, 1988. "Blogeochemical Aspects of Atmospherle Methane," Global Biogeochemical Cycles 2:299-327.

*Cline, William R., 1989, "Political Economy of the Greenhouse Effect," Institute for International Economics, August.

Commission of the European Communitles, Energy in Europe Major Themes in Energy, 1989, Brussels.

*Congressional Budget Office. "Carbon Charges as a Response to Global Warming: The Effects of Taxing Fossil Fuels." Forthcoming, August 1990.

*Council of Cireat Lakes Governors, 1985. Blomass Resources: Generating Jobs and Energy. Great Lakes Regional Biomass Energy Program, November.

Criner, G.K., el al., 1986. "An Economic Analysis of' a Maine Dairy Farm Anacrobic Digester," Maine Agricultural Experiment Station Bulletin 816, University of Maine.

Crutzen, P.J., 1983. "Atmospheric Interactions-Homogeneous Gas Reactions of C-, N-, and S-Containing Compounds," in The Major Blogeochemical Cycles and their Interactions, Scope 21, B. Bolin and R. B. Cook, eds., John Wiley \& Sons, Chichester. 
1. Asclmann, and W. Seller, 1986. "Methane Production by Domestic Animals, Whld Ruminants, Other Herblyorous Fauna, and Humans," Tellus 38B:271--284,

Duiry Manure Managemonl, NRAES-31, 1989, Procecdings l'om the Dalry Manure Manngement Symposilum, Syracusc, Fobruary 22--24.

Darmstadter, Joel, and Jac Edmonds, 1988. "Human Development and Carbon Dioxide Emisslons: 'The Current Pleture and the Long-Term Prospects," Greenhouse Warming: Abatement and Adaplation, Resources lor the Future,

Davts, G.R., 1989. "Responding to the Challenge of Clobul Warming: The Role of Energy Efflicient Technologies," paper presented at a Workshop on Energy and Environmental Modellng and Pollcy Analysils, MIT Cenler for Energy Polley Rescarch.

Decker, W.L., V.K. Jones, and R. Achutuni, 1985. "The Impact of $\mathrm{CO}_{2}$-Induced Climate Change on US Agrlculture," in M.R. White ed., "Characterlzation of Information Recultements for Studles of $\mathrm{CO}_{2}$ Effects: Wator Resources, Agriculture, Filshorles, Forests and Human Health." U.S, Department of Energy, DOE/ER-(1236, Washington, DC.

Detweiler, R.P., and C.A. Hall, 1988. "Tropical Forests and the Global Carbon Cycle," Sclence 239:4247.

Dicks, M.R., 1982. "Economio Feasibilly' of Methane Production in Tunisia," Unpublished M.S. 'Thesis, Department of Agricultural Economics, University of Mlssouri.

*Difiglio, C., K.G., Duleep, and D.L. Greene, 1989 (forthcoming). "Cost Effectiveness of Future Fuel Economy Improvements," The Energy Journal.

Easterling, William E. III, Martin L. Parry, and Picrric R, Crosson, 1988. "Adapting Future Agriculture to Changes in Climate." Greenhouse Warming: Abatement and Adaptation, Resources for the Future.

*Edmonds, Jae A., 1989. "A Second Generation Greenhouse Gus Emissions Model: Oulline of Design and Approach," paper presented at a Workshop on Energy and Environmental Modeling and Policy Analysis, MI'T Center f'or Energy Policy Research.

*___ and John Reilly. "Global Energy and CO2 to the Year 2050," The Energy Journal, Vol.4, No.3, p. $21-47$.

Finland (Government of) Ministry of Agrlculture and Forests, Council for Natural Resources, 1989. "Response Strategles: Boreal Forests," paper submitted to IPCC/RSWG, October 1989

Freidli, H., H. Lotscher, H. Oeschger, U. Siegenthaler, and B. Stauffer, 1986. "Ice Cor Record of the ${ }^{13} \mathrm{C} /{ }^{12} \mathrm{C}$ Ratio of Atmospheric Carbon Dloxide in the Past Two Years," Nature 324:237-238.

*Foy, Douglas I., 1989. Testimony on behalf of the Conservation Law Foundation of New England, U,S. Department of Energy Field Hearings on the National Energy Strategy, Providence, RI, December 1; corrected version filed December 29.

* __... Personal Communication, January 11, 1990. 
Fulkerson, W, et al. "Cilobal Warming: An linergy 'Technology R \& D Challonge," Sclenec 246:868.

George C. Marshall Insitute, 1989. "Sclone Perspectlves on the Greenhouse Problom," Washington, DC.

*Gellings, C.W., el al., 1990. "Efficionl Electriclty Use: Esthnates of Maxlmum Enorgy Savlngss." Electrie Power Reseurch Institute, CU.6746 Rosearch Project 2788, Final Report, March 1990).

*Olbbs, M.J, 1984. "Economic Analysis of' Sea Level Rlse: Mothods and Results," In M.C. Barlh and J,O, 'Tllus, eds., "Cirenhouse El'fect and Sen Level Rlse: A Challenge lor" Thals Generation," New York.

Gilbertson, C.B., D.L. Van Dyne, C.J. Clanton, and R.K. While, 1978. "Estimating Quantly and Constltuents in Livestock and Poultry Manure Restdue as Reflected by Manngement Systems," Tratsuctions of the ASAE, 22.

Goldemberg, J, T. Johansson, A, Reddy, and R. Willams, 1989. "Changing the Pollileal Economy of Energy," paper presented at a Workshop on Energy and Environmental Modeling and Polloy Analysls, MIT Center for" Energy Polloy Rescarch.

1989. "Energy Use in Developing Counirles-A Thought Expertment," paper presented at a Workshop on Energy and Environmental Modeling and Pollcy Analysis, MI'T Center for Energy Policy Research.

, cl al, 1988. "Encrgy for a Sustainable World," Wilcy Easlcm Limited, New Dolhi.

Gunnerson, C.G., and D.C. Stuckey, 1986. "Integrated Resource Recovery Anaeroble Digestion: Principles and Practices for Blogas Systems," World Bank Technical Paper No.49, Washington, DC,

Gushec, D.E., R.E. Morrison, and J.R. Justus, 1989, "Global Cllmate Change: The Sclence, Sources, Agricultural and Forcstry Impacts, and Proposed Pollcy Responses," in Agriculture, Forestry, and Global Climate Change--A Reader, prepared by the Congressional Rescarch Service and the Lubrary of Congress, Washinglon, DC.

*Hansen, J., 1. Fung, A. Lacls, D. Rind, S. Lebedeff, R, Ruedy, and G. Russell, 1988. "Cllobal Climate Changes as Forecist by Goddard Institule of Space Studies Three-Dimensional Model," Joumal of Geophysical Research 93:9341-9364.

*Hansen, L., 1990. "The Effects of Climate and Weather on Corn Ylelds," unpublished munuscript, USDA, Economic Research Service, Washington, DC,

* Hausman, Jerry, 1979. Individual Discount Rates and the Purchase and Utilization of Energy Using Durables. Rand Joumal of Economics, 10:33-54.

Heffernan, Kathleen, and Lester B. Lave, 1989. "Adjusting to Greenhouse Effects: Exploring the Economic Costsu to Rich and Poor Countries," paper presented at a Workshop on Energy and Environmental Modeling and Policy Analysis, MIT Center for Energy Policy Research.

Hekstra, Gjerrit P., 1988. "Sea-Level Rise: Regional Conseguences and Responses," Greenhouse Warming: Abatement and Adaptation, Resources for the Future.

Hills, D.J. and D.W, Roberts, 1980. "Basic Fundamentals of Methane Generation from Agricultural Waste," unpublished paper, Department of Agricultural Englneering, University of Callfornia, Davis. 
Hirst, E., 1989a. "Foderal Roles to Realize National Enorgy-Efficiency Opportunitios in the 1990s," prepared by the Oak Ridge National Laboratory tor the U.S. Department of Energy, ORNL/CON-29().

1989b. "Electric-Utility Energy Efficiency and Load Management Programs; Resources for the 1990s", prepared by the Oak Ridge Nationa! Laboratory for the U.S. Department of' Energy, ORNL/CON-285.

Hodges, D. et al, 1989. "Evaluating Potential Economle Impacts of Global Climate Change on Forestry in the Southem United States, Resource Management and Optimlzation," Vol,6, No.3.

Houghton, R.A. et al., 1987. "The Flux of Carbon From Terrostrial Ecosystems to the Almosphere in 1980) Dur to Changes in Land Use: Geographle Distribution of the Global Flux," Tellus 39B:122-139.

*Hull, C.H.J. and J.G, Titus (eds,), 1986. "Greenhouse Effect, Sea Level Rise, and Sallnity in the Delaware Estuary." U.S. Environmental Protection Agency, Washington, DC.

International Rice Research Instltute, 1986, "World Rice Statistics: 1985," Manila.

Jewell, W.J., ot al., 1980. "Anacroble Fermentation of" Agricultural Residue: Potential for Improvement and Implementation," report prepared by Cornell University for the U.S. Dept. of Energy, DOE/ET/20051-T1.

Joharsson T. B., et al., 1989. "Eledricity Effictent End-Use and Now Generation Technologies, and Their Planning Implications," Lund Undversity Press: Lund, Sweden.

Jones, D.D., J.C. Nye, and A.C. Dale. "Methane Generation from Livestock Waste," AE-105, Cooperative Extension Service, Purdue University, West Lafayette, IN.

Jorgenson, Dale W. and Peter J. Wilcoxen, 1989. "Environmental Regulation and U.S. Economic Growth," paper presented at a Workshop on Energy and Environmental Modeling and Policy Analysis, MIT Center for Energy Policy Research.

Joskow, Paul L., 1990, "Understanding the 'Unbundled' Utility Conservation Bldding Proposal," Public Utilities Fortnighily, January 4.

Khalil, M.A.K., and R.A. Rasmussen, 1987. "Nitrous Oxide: Trends and Global Mass Balance Ovor the Last 3000 Years," Annals of Glaciology 10:73-79.

Kalkstein, L., 1990. "Global Climate Change and Human Health: What Are the Potential Impacts?", Encyclopedia Britannici Medical and Health Annual, forthcoming.

1989. "The Impact of $\mathrm{CO}_{2}$ and Trace Gas-Induced Cllmate Changes Upon Human Mortality," in Potential Effects of Climate Change on the United States, J. Smith and D. 'Tirpak, eds., U.S. Environmental Protection Agency, Washington DC.

, and K.M. Valimont, 1987. "Climate Effects on Human Health," in Potential Effects of Future Climate Changes on Forests and Vegetation, Agriculture, Water Resources, and Hurnan Health, EPA Science and Advisory Committee Monograph No. 2538, Washington, DC. 
*Kane, Sally, John Reilly, and Rhonda Bucklin, 1989. "Implications of the Greenhouse Effect for World Agricultural Commodity Markets," presented at the Western Economic Assoctation Conference, Lake Tahoc, Callfornla.

*Kaya, Yolchi, 1989. "Impact of Carbon Dloxide Emission Control on GNP Growth: Interpretation of Proposed Scenarios" IPCC/RSWG mimeo, May 8.

*___ Ryuji Matsuhashl, and Kenjt Yamajl, 1989. "The Grand Strategy for Global Warming," Paper presented at the Tokyo Conference on Clobal Development and Human Response T'oward Sustainable Development, September.

* Keyes, Dale, and Stephen Seidel, 1983. "Can We Delay a Greonhouse Warming? The Efrectiveness and Feasibllity of Options to Slow a Build-up of Carbon Dioxide in the Atmosphere." U.S. Environmental Protection Agency, Office of Policy, Planning and Evaluation.

Koelsch, R.K., W.J. Jewell, and R.J. Cummings, 1986. "Cogeneration of Electricity and Heat from Blogas," Applied Engineering in Agriculture, Vol.2, No.2.

Landgrebe, A., et al., 1989. "Atmospherle Impacts of Fucl Cell and Battery Technology," paper presented at the Ninth Electrochemical Contractors' Mecting: Washington, DC.

Lanly, J.P., and J. Clement, 1979. "Present and Future National Forest and Plantation Areas in the Tropics," Unasylva, No.123.

*Lashof, Daniel A., and Dennis Tirpak, eds, 1989. Policy Options for Stabilizing Global Climate: Draft Report to Congress, U.S. Environmental Protection Agency, Washington, DC.

*Lashof, Daniel A., and Dilip R. Ahuja, 1989. "Relative Global Warming Potentials of Greenhouse Gas Emissions," manuscript, Natural Resources Defense Council.

Lave, Lester, 1989. "The Greenhouse Effect: What Government Actions are Needed?" paper presented at a Workshop on Energy and Environmental Modeling and Policy Analysis, MIT Center for Energy Policy Research.

Lerner, J., E. Matthuws, and I. Fung, 1988. "Methane Emission From A.nimals: A Global High-Resolution Database," Global Biogeochemical Cycles 2:139-156.

Linder, K.P., and M.R. Inglis, 1989. "The Potential Impacts of Climate Change on Electric Utilities: Regional and National Estimates," in The Potential Effects of Global Climate Change on the United States, J.B Smith and D.A. Tirpak, eds., U.S. Environmental Protection Agency, EPA 230-05-89-058, Washington, DC.

Linder, K.P., M.J. Gibbs, and M.R. Inglis, 1987. "Potential Impacts of Climate Change on Electrle Utilities," New York State Energy Research and Development Authority NYSERDA 88-2, A.lbany.

*Manne, Alan S., and Richard G. Richels, 1989. " $\mathrm{CO}_{2}$ Emission Limits: An Economic Anaiysis for the USA", paper presented at a Workshop on Energy and Environmental Modeling and Policy Analysis, MIT Center for Encrgy Policy Research. 
*Manne, Alas S., and Richard G. Richels, 1990. "Global $\mathrm{CO}_{2}$ Emission Reductions - the Impacts of Rising Energy Costs," paper presented to the International Institute for Applied Systems Analysis, January 1990.

* Marks, Robert E., Peter McLennan, Richard Schodde, and Peter L. Swan, 1989. "The Feasibility and Implications for Australia of the Adoption of the Toronto Proposal for Carbon Dioxide Emission." Working Paper 89-032, Australian Graduate School of Management, November.

Marland, G., 1988. "The Prospect of Solving the $\mathrm{CO}_{2}$ Problem Through Global Refurestation," U.S. Department of Energy, DOC/NBB-0082, Washington, DC.

T.A. Boden, R.C. Griffin, S.F. Huang, P. Kanciruk, and T.R. Nelson, 1988. "Estimates of $\mathrm{CO}_{2}$ Emissions from Fossil Fuel Burning and Cement Manufacturing Using the United Nations Energy Statistics and the U.S. Bureau of Mines Cement Manufacturing Data," Carbon Dioxide Information Analysis Center, No. 3176.

Miller, P.M., J.H. Eto, and H.S. Geller, 1989. "The Potential for Electricity Conservation in New York State," American Council for an Energy-Erficient Economy, draft paper, Washington, DC.

Mills, E., J.P. Harris, and A.H. Rosenfeld, 1988. "U.S. Energy Trends and Policies for Developing 'Demand-Side Resources'," Lawrence Berkeley Laboratory LBL-24920, Berkeley.

Mintzer, Irving, 1989. "Projecting Future Energy Demand in Industrialized Countries: An End-Use Oriented Approach," paper presented at a Workshop on Energy and Environmental Modeling and Policy Analysis, MIT Center for Energy Policy Research.

*Miranowski, J.A., J. Hrubovcak, and J. Sutton, 1989. "The Effect of Commodity Programs on Resource Use," paper presented at the CARP Symposium, Baltimore, MD.

*Moskovitz, D., 1988. "Will Least-Cost Planning Work Without Significant Regulatory Reform?," paper presented at the Least Cost Planning Seminar, National Association of Regulatory Utility Commissioners, Aspen.

*Moulton, Robert, and Ken Richards, 1989. "Carbon Sequestration Through Forestation," U.S. Forest Service, draft report, Washington, DC.

*National Climate Program Office, 1989. "Climate Impact Response Functions," Report of a Workshop initiated by OMB, USDA, and NCPO, September 11-14, Coolfont, West Virginia.

*National Research Council, 1987. "Current Issues in Atmospheric Change." Washington, DC.

National Rescarch Council, 1979. "Energy in Transition 1985-2010, Committee on Nuclear and Alternative Energy Systems," W.H. Freeman, San Francisco.

Natural Resources Defense Council, 1989. "Cooling the Greenhouse. Vital First Steps to Combat Global Warming," Washington, DC.

Neftel, A., E. Moor, H. Oeschger, and B. Stauffer, 1985. "Evidence from Polar Ice Cores for the Increase in Atmospheric $\mathrm{CO}_{2}$ in the Past Two Centuries," Nature 315:45-47.

*New York State Energy Plan, 1989. Albany. 
*Nordinaus, William D., 1990. "A Survey of Estimates of the Cost of Reduction of Greenhouse Gas Emissions." Yale University, New Haven, CT.

Nordhaus, William D., 1989. "The Economics of the Greenhouse Effect," paper presented at a Workshop on Energy and Environmental Modeling and Policy Analysis, MIT Center for Energy Policy Research.

*Nordhaus, William D., 1990. "To Slow or Not to Slow: The Economics of the Greenhouse Effect." Yale University, Nèw Haven, CT.

1982. "How Fast Should We Graze the Global Commons?," American Economic Review, 72:2.

Ogden, Joan M., and Robert H. Williams, 1989. "Solar Hydrogen: Moving Beyond Fossil Fuels," World Resources Institute, Washington, DC.

Olson, J.S., J.A. Watts, and L.J. Allisen, 1983. "Carbon in Live Vegetation of Major World Ecosystems," Report ORNL-5862, Oak Ridge National Laboratory, Oak Ridge, Tennessee.

Paltridge, Garth, Susan Offutt, and John Reilly, 1989. "Response to Climate Change: A Framework for Cost-Benefit Analysis at the National Level," draft paper, USDA/ERS.

Parry; M.L. et al., 1987. "The Potential Impact of Climatic Variations on Agriculture," Intemational Institute for Applied Systems Analysis and United Nations Environment Program.

*__ T.R. Carter, and N.T. Konijn (eds.), 1988a. "The Impact of Climatic Variations on Agriculture," Vol.1: Assessments in Cool Temperate and Cold Regions, IIASA/UNEP. Boston: Kluwer Academic Publishers.

*__ T.R. Carter, and N.T. Konijn (eds.), 1988b. "The Impact of Climatic Variations on Agriculture," Vol.2: Assessments in Semi-Arid Regions, IIASA/UNEP. Boston: Kluwer Academic Publishers.

et al., 1989. "The Protential Impact of Climatic Change on Agriculture and Land Use," draft paper prepared for Working Group II of the IPCC, University of Birmingham.

Pearman, G.I., D. Etheridge, F. deSilva, and P.J. Fraser, 1986. "Evidence of Changing Concentrations of Atmospheric $\mathrm{CO} 2, \mathrm{~N}_{2} \mathrm{O}$ and $\mathrm{CH}_{4}$ from Air Bubbles in Antarctic Ice," Nature 320:248-255.

Peart, Jones, and Curry. "Impact of Climate Change on Crop Yield in the Southeastern U.S.: A Simulation Study," Study conducted for the U.S. Environmental Protection Agency, University of Florida.

Persson, S.P.E., et al., 1979. "Agricultural Anaerobic Digesters: Design and Operation," Pennsylvania State University Bulletin 827, University Park, PA.

, and H.D. Bartlett, 1981. "Biogas Engines for Agricultural Motor-Generators," paper presented to the American Society of Agricultural Engineers, Chicago, December 15-19.

Peskin, Henry M., 1989. "Accounting for Natural Resource Depletion and Degradation in Developing Countries," paper presented at a Workshop on Energy and Environmental Modeling and Policy Analysis, MIT Center for Energy Policy Research. 
*Pirkey, D.B., and R.M. Scheer, 1988. "Energy Conservation Potential: A Review of Eight Studies," Proceedings of the 1988 ACEEE Summer Study on Energy Efficiency in Buildings, American Council for an Energy Efficient Economy, Washington, DC.

*Plotkin, Steven E., 1989. Statement before the Subcommittee on Energy and Power, Committee on Energy and Commerce, U.S. House of Representatives, July 12.

Postel, S. and L. Heise, 1988. "Reforesting the Earth," Worldwatch Institute No.83, Washington, DC.

Prinn, R.G., 1988. "How Have the Atmospheric Concentrations of Halocarbons Changed?," in The Changing Atmosphere, F.S. Rowland and I.S.A. Isaksen, eds., John Wiley \& Sons, Chichester.

*Ramanathan, V., R.J. Cicerone, H.B. Singh, and J.T. Kiehl, 1985. "Trace Gas Trends and Their Potential Role in Climate Change," Journal of Geophysical Research 90:5547-5566.

*Reilly, John, and J. Edmonds, 1985. "Changing Climate and Energy Modeling: A Review," The Energy Journal, Vol.6, No.3. p.137-54.

* J.A. Edmonds, R.H. Gardner, and A.L. Brenkert, 1987. "Uncertainty Analysis of the IEA/ORAU CO2 Emissions Model," The Energy Journal, Vol.8, No. 3. p.1-29.

Reister, David B., 1989. "Energy Technology R\&D: What Could Make a Difference?," paper presented at a Workshop on Energy and Environmental Modeling and Policy Analysis, MIT Center for Energy Policy' Research.

Ritchie, Joseph, Baer, and Chou, "Effects of Global Climate Change on Agriculture: Great Lakes Region," Study conducted for the U.S. Environmental Protection Agency, Michigan State University.

*Roningen, Vernon O., 1986. "A Static World Policy Simulation (SWOPSIM) Modeling Framework," ERS Staff Report AGE860625, Washington, DC.

Rosenberg, Norman J., 1989. "Policy Options for Adaptation to Climate Change," Resources for the Future, Washington, DC.

1986. "A Primer on Climatic Change: Mechanisms, Trends, and Projections," Resources for the Future, Washington, DC.

William E. Easterling, Pierre R. Crosson, and Jocl Darmstadter, editors, 1988. "Greenhouse Warming: Abatement and Adaptation," Resources for the Future."

Rosenzweig, Cynthia, "Potential Effects of Climate Change on Agricultural Production in the Great Plains," Study conducted for the U.S. Environmental Protection Agency, Goddard Space Flight Center/Columbia University.

Ross, M. December 6, 1989. Personal Communication.

Rotty, R.M., 1986. "Estimates of $\mathrm{CO}_{2}$ from Wood Fuel Based on Forest Harvest Data," Climate Change, Vol.9.

Sant, R.W., 1979. "The Least Cost Energy Strategy," Carnegie-Mellon University Energy Productivity Center: Arlington, VA. 
*Santer, Benjamin, 1985. "The Use of General Circulation Models in Clinate Impact Analyses - A Preliminatly Study of the Impacts of a CO2 Induced Climate Change on West European Agriculture," Climatic Change, No.7.

Santini, D.J., et al., 1989. "A Characterization of the Attributes of Transportation Technologies Which Are Relevant to the Estimation of Greenhouse Gas Reductions in the Transportation Sector," Argonne National Laboratory: Argonne, IL.

, et al., 1989. "Alternative Greenhouse Gas Reduction Policies for Application to Light Duty Vehicle Use by Houscholds," draft paper, Argonne National Laboratory: Argonne, IL.

Sathaye, Jayant A., 1989. "Modeling Long-Term LDC Energy Use to Assess Impacts on the Global Environment," paper presented at a Workshop on Energy and Environmental Modeling and Policy Analysis, MIT Center for Energy Policy Research.

Schipper, Lee, 1989. "Energy Efficiency and Environmental Policy: Progress, Plateau, or Passe," paper presented at a Workshop on Energy and Environmental Modeling and Policy Analysis, MIT Center for Encrgy Policy Research.

Schneider, Stephen H., Norman J, Rosenberg, 1988. "The Greenhouse Effect: Its Causes, Possible Impacts, and Associated Uncertainties." Greenhouse Warming: Abatement and Adaptation, Resources for the Future.

*Searle, Milton F., and Chauncey Starr, 1989. "Global Electricity Futures: Demand and Supply Altematives." Paper presented at American Nuclear Society Annual Mecting, November.

Sedjo, R.A., and A.M. Solomon, 1988. "Climate and Forests," paper presented to the Workshop on Controlling and Adapting to Greenhouse Warming sponsored by Resources for the Future.

Sciler, W., and R. Conrad, 1987. "Contribution of Tropical Ecosystems to the Global Budgets of Trace Gases, Especially $\mathrm{CH}_{4}, \mathrm{H}_{2}, \mathrm{CO}$, and $\mathrm{N}_{2} \mathrm{O}$ ", in Geophysiology of Amazonia," R.E. Dickinson, cd., John Wilcy \& Sons, New York.

Shaffer, S., 1989. "Biogas Production from Dairy Manure: A Case Study of the Langerwerf Dairy, Durham, Califormia," unpublished report, Califomia Department of Food and Agriculture, Sacramenta, CA.

Siegenthaler, V., and H. Oeschger, 1987. "Biospheric $\mathrm{CO}_{2}$ Emissions During the Past 200 Ycars Reconstructed by Deconvolution of Ice Core Data," Tellus 39B:140-154.

Solar Energy Research Institute, 1989. "The Potential of Renewable Energy: An Interlaboratory Analytic: Paper," Office of Policy, Planning and Analysis, U.S. Department of Enengy, Washington, DC. Mass.

1981. "A New Prosperity: Building a Sustainable Energy Future," Brick House Publishing: Andover,

*Smith, Joel B. and Dennis Tirpak (eds.), 1989. The Potential Effects of Global Climate Change on the United States. Draft Report to Congress. U.S. Environmental Protection Agency, Washington, DC.

Splinter, W.E. and D.D. Schulte, 198\% "Energy Integrated Swine Farm System in Nebraska," U.S. Dept. of Encrgy, Idaho Operations Office, DOE/CS/40378. 
Stauffer, B., G. Fischer, A. Neftel, and H. Oeschger, 1985. "Increase of Atmospheric Methane Recorded in Antarclic Ice Cores," Science 229:1386-1389.

*Steinberg, M., 1983. "An Analysis of Conepts for Controlling Atmospheric Carbon Dioxide." U.S. Department of Energy, TR007, DOE/CH/(0)016-1, December.

*____ and H.C. Cheng, 1987. "Advanced Technologies for Reducing $\mathrm{CO}_{2}$ Emissions." Document No. 40730, Brookhaven National Laboratory, Brookhaven, NY.

*Stuntz, Linda G., 1989. Statement before the Subcommittee on Energy and Power, Committee on Energy and Commerce, U.S. House of Representatives, July 13.

*Tennessec Valley Authority, 1989. "Economic Impacts of Industrial Wood Energy Use in the Southeastert U.S." Draft.

United Nations, 1987. 1985 Energy Statistics Yearbook, New York.

United Nations Food and Agriculture Organization, 1989. "Implications of Climate Change for Food Security," paper prepared for Resource Use and Management Subgroup of Working Group III of the IPCC.

United Nations Food and Agriculture Organization, 1982. "Conservation and Development of Tropical Forest Resources," Forestry Paper 37, Rome.

U.S. Department of Commerce, 1987. "Fixed Reproducible Tangible Wealth in the United States, 1925-85." Bureau of Economic Analysis, Washington, DC.

U.S. Department of Energy, 1989. "A Preliminary Analysis of U.S. $\mathrm{CO}_{2}$ Emissions Reduction Potential from Energy Conservation and the Substitution of Natural Gas for Coal in the Period to 2010," DOE/NBB-(0)85.

, Climate Change Committee, October 1989. "Energy and Global Change," Washington, DC.

1989. "Final Programmatic Environmental Impact Statement Clean Coal Technology Demonstration Program," DOE/EIS-0146, Washington, DC.

* ___ 1989. "Energy Conservation Trends: Understanding the Factors that Affect Conservation Gains in the U.S. Economy," DOE/PE-(0)92, Washington DC.

, 1989. "Energy and Climate Change: Report of the DOE Multi-Laboratory Climate Change Committee." Draft of December 1989. UCRL-102476. Lawrence Livermore National Laboratory.

, December 8, 1989. Office of Environment, Office of Nuclear Energy, Personal Communications.

U.S. Environmental Protection Agency, 1989. "Costs and Benefits of Phasing Out Production of CFCs and Halons in the United States."

U.S. Forest Service, 1989. "Tree Planting and Forest Improvement to Reduce Global Warming." Draft Report, Washington, DC. 
Van Dyne, D.L., and C.B. Gilbertson, 1978. "Estimating U.S. Livestock and Poultry Manure and Nutrient Production," U.S. Department of Agriculture, ESCS, ESCS-12.

Van Dyne, D.L., and C.B. Gilbertson, 1979. "Estimated Inventory of Livestock and Poultry Manure Resources in the United States," Agricultural Wastes: An Intemational Journal, Vol.1, No.4.

Veselka, T., 1989. Personal Communicalion.

Waybright, R, 1989. "Waste Not! Want Not!," conference paper to "Commercializing Industrial Uses for Agricultural Commodities," Overland Park, Kansas, March 28-29.

Walsh, J.L., et al., 1988. Handbook on Biogas Utillzation, published for U.S. Department of Energy by the Southeastem Regional Biomass Energy Program, Tennessec Valley Authority, Muscle Shoals, Alabama.

*Wenders, John T., 1986. "Economic Efficiency and Income Distribution in the Electric Utility Industry." Southem Economic Joumal, April.

*Whalley, John, and Randall Wigle, 1989. "Cutting $\mathrm{CO}_{2}$ Emissions: the Effects of Alternative Policy Approaches." Mimeo, University of Western Ontario, September.

White, M.R., and I. Hertz-Picciotto, 1985. "Human Health: Analysis of Climate Related to Health", in Characterization of Information Requirements for Studies of $\mathrm{CO}_{2}$ Effects: Water Resources, Agriculture, Fisheries, Forests, and Human Health. U.S. Department of Energy, Washington DC.

Williams, Robert H., 1989. "Innovative Approaches to Marketing Electric Efficiency," paper presented at a Workshop on Energy and Environmental Modeling and Policy Analysis, MIT Center for Energy Policy Research.

*Williams, Robert H., 1989. "Low-Cost Strategies for Coping with $\mathrm{CO}_{2}$ Emission Limits." Center for Energy and Environmental Studies, Princeton University, Princeton, N.I.

*Williams, Robert H., 1990. "Will Constraining Fossil Fuel Carbon Dioxide Emissionis Really Cost So Much?" Center for Energy and Environmental Studies, Princeton University, Princeton, NJ.

Womach, J., 1989. "Impacts of Global Climate Change on Agriculture." Agriculture, Forestry, and Global Climate Change-A Reader, prepared by the Congressional Research Service and the Library of Congress, Washington, DC.

*Wuebbles, D.J. and J. Edmonds, 1988. A Primer on Greenhouse Gasses. U.S. Department of Energy, Carbon Dioxide Research Program, report DOE/NBB0083.

*Yoshino, M., T. Horie, H. Scino, H. Tsujii, T. Uchijima, and Z. Uchijima, 1988. "The Effects of Climatic Variations on Agriculture in Japan," Part VI in the Impact of Climatic Variations on Agriculture, Vol.1: Assessments in Cool Temperate and Cold Regions, M.L. Parry, eds. 

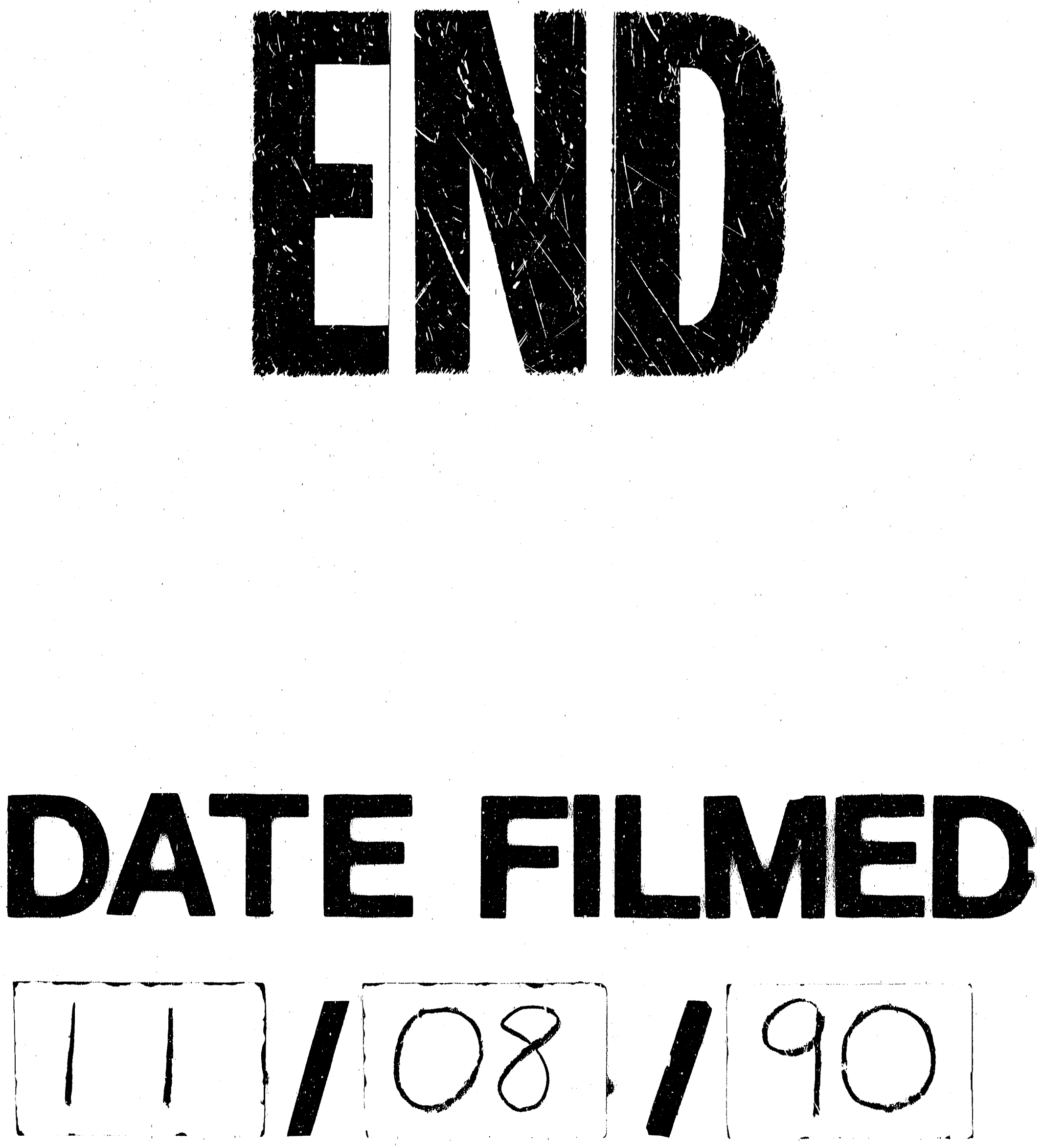
